\title{
Multi-objective optimization of the geometry of single-family housing to improve thermal performance
}

\author{
Otimização multi-objetivo da geometria de habitações \\ sociais unifamiliares visando a melhoria do desempenho \\ térmico
}

\section{Angélica Saccol Berleze \\ Alice de Barros Horizonte Brasileiro Marcos Martinez Silvoso}

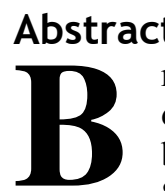

razil's current housing deficit exceeds 6 million homes and a demand of 10 million homes for low-income families is expected by 2040 . On the other hand, during the last 10 years, approximately 850,000 social housing units have been delivered through the "My House, My Life" Program - (Programa Minha Casa, Minha Vida - PMCMV). Despite these numbers, several studies suggest some problems related to the low quality of the houses. This article aims to investigate the design parameter related to the geometry of social housing in Chapecó/SC, Brazil, which contributes to the achievement of the best thermal performance. Parametric methods and multi-objective optimizations were utilized, two objectivefunctions were optimized regarding the degree-hours for cooling and heating. The results showed significant improvements, reaching up to $98 \%$ during the hot period and $49 \%$ during the cold period. Guidelines were defined to assist architects in the early-phases of the social housing design based on the climate of the target region. However, the best design solutions for thermal comfort throughout the year can only be indicated with computational methods.

Keywords: Social Housing. Thermal Performance. Parametric Tools. Multi-objective Optimization. Genetic Algorithms.

\section{Resumo}

O déficit habitacional atual do Brasil supera 6 milhões de moradias e pesquisadores ainda preveem um aumento de demanda de 10 milhões de habitações para a população de baixa renda até 2040. Por outro lado, nos últimos 10 anos foram entregues cerca de 850 mil unidades para essa mesma população, através do Programa Minha Casa Minha Vida. Apesar da expressividade dos números, diversos estudos apontam para a baixa qualidade das moradias, dentre eles em relação ao conforto térmico. A partir disso, o objetivo desse artigo foi investigar as configurações de parâmetros relativos à geometria de habitações sociais em Chapecó/SC que contribuem para alcançar os melhores desempenhos térmicos. Com o auxílio de métodos paramétricos e otimizações multiobjetivo, foram otimizadas duas funçõesobjetivo referentes aos graus-hora de resfriamento e aquecimento. Os resultados mostraram melhorias significativas, chegando a $98 \%$ no período quente e $49 \%$ no período frio. A partir disso foi possível elencar diretrizes a fim de auxiliar arquitetos nas definições iniciais do projeto arquitetônico de habitações sociais adequadas ao clima da região. Além disso, foi possível perceber que quando o objetivo é priorizar o desempenho ao longo do ano todo, apenas métodos computacionais podem nos indicar as melhores configurações de fechamentos.

Recebido em 27/07/20 Aceito em 18/10/20
Palavras-chave: Habitação Social. Desempenho Térmico. Ferramentas Paramétricas. Otimização Multiobjetivo. Algoritmos Genéticos.

BERLEZE, A. S.; BRASILEIRO, A. de B. H.; SILVOSO, M. M. Multi-objective optimization of the geometry of single-family housing to improve thermal performance. Ambiente Construído, Porto Alegre, v. 21, n. 2 , p. 41-65, abr./jun. 2021. 


\section{Introduction}

Brazil has an estimated housing deficit of 6.36 million households of which 5.57 million (87.7\%) are located in urban areas (FUNDAÇÃO..., 2020). Givisiez and Oliveira (2018) predict a demand of 29.5 million homes by 2040, which corresponds to the construction of more than 1 million housing units per year over the next 20 years. About a third of this production belongs to classes 1 and 2, whose monthly income is less than $\mathrm{R} \$ 2,600.00$.

On the other hand, since 2009, Minha Casa Minha Vida Program (PMCMV) has enabled the construction of more than 2 million homes, and by 2017, more than 850 thousand housing units were delivered to families with monthly income up to R\$ $1,800.00$ (Band 1 of the PMCMV) (CAIXA..., 2018). Since the destabilization of the economy in 2015, however, there was a reduction in the number of housing units contracted by the Program and, since 2018, there has been no disclosure of new contracts for Band 1. In 2019, the year in which the PMCMV completed 10 years of existence, the government expected to deliver only 230,000 units (G1, 2020).

Moreover, between 2009 (when the PMCMV was cread) and 2015 (last year with available data), the housing deficit in Brazil increased 6\% (FUNDAÇÃO..., 2020). Thus way, the Program's production was not able to effectively reduce the housing deficit, although it contributed to slow down its progress (BRASIL, 2017).

Regarding quality, what it is seen throughout the Brazilian territory is a high classification of houses, whose project disregards the cultural and environmental diversity of the different regions of the country (BORTOLI; VILLA, 2020). Even with a Brazilian standard related to performance in use, NBR 15575, houses are generally built without considering the local climate, the thermal comfort of the residents and the quality of the built environment due to the cost limitation within the PMCMV (SANTOS; PORTO; SILVA, 2020; TRIANA; LAMBERTS; SASSI, 2015; TUBELO et al., 2018).

Considering housing maintenance costs in Brazil, the residential sector was responsible for electricity consumption in 2018 , corresponding to $25.4 \%$ of the $50.5 \%$ consumed by the building sector (commercial, public and residential) (EMPRESA..., 2019). Most of this consumption comes from single-family homes, which accounted for 86\% (59 million) of Brazilian household types in 2016 (INSTITUTO BRASILEIRO..., 2020).

According to Eletrobras (2019), 77\% of Brazilian households consume up to $200 \mathrm{kWh}$ of electricity per month. This consumption is often linked to inefficient equipment. In the housing complex object of this study, an average consumption of $145 \mathrm{kWh}$ was verified in the housing units varying from $103 \mathrm{kWh}$ in the summer to $190 \mathrm{kWh}$ in the winter (BERLEZE, 2020). This increase in consumption in winter may be linked to the required high temperature of the electric shower, as well as the use of electric heaters.

Even in a temperate climate, with temperatures varying from $0{ }^{\circ} \mathrm{C}$ in winter to $35^{\circ} \mathrm{C}$ in summer (with an even more extreme apparent temperature), the existence of a fan was verified in about $65 \%$ of the units and HVAC in only 1\% (BERLEZE, 2020). Therefore, the use of equipment for air conditioning in this set of the PMCMV is low. Residents rely almost exclusively on the thermal performance of materials and building to maintain thermal comfort. As a result, energy consumption is relatively low in low-income housing, while there is a need for buildings with passive thermal conditioning attributes to provide greater thermal comfort to residents.

In 2010, the Ministry of Mines and Energy, INMETRO, PBE and PROCEL launched the first regulation for the evaluation of energy efficiency in residential buildings in Brazil, the RTQ-R. Currently, labeling is a voluntary process, but the National Energy Efficiency Plan provides for the compulsory adhesion of residential buildings by 2030 (PROCEL, 2014). In this sense, it is expected that this compulsory adhesion would start with the units produced through government housing programs, which reaffirms the need for studies involving energy efficiency, performance and thermal comfort in social housing.

Energy-efficient and climate-adapted buildings have a high potential for reducing energy consumption and greenhouse gas emissions (UNITED..., 2020). The project settlements regarding form and envelope are the ones that impact the most on naturally ventilated constructions' performance. Therefore, it is essential to be able to predict the buildings' performance, whether related to their energy consumption, $\mathrm{CO}_{2}$ emissions, thermal comfort, indoor air quality, or other relevant aspects.

For this matter, there has been an increase in the number of researches and in the development of performance-based design methods. Thermal and energy simulation softwares have been in use for some 
decades. However, these tools are more widely associated with trial and error method studies, which leads to an under-use of these softwares' potential. These methods cannot cope with the complexity of interactions between so many design variables and objectives required in more efficient buildings. Although the result may be relatively good, there is a small chance for it to achieve the best possible result (MAGNIER, 2008).

On the other hand, researchers have pointed to the high potential of computational tools, more specifically those based on the use of algorithms, to assist in generating most efficient forms for buildings (FONSECA et al., 2017; SANTANA, 2016; NGUYEN; REITER; RIGO, 2014). New computer simulation applications have emerged in a promising way, like, for example, parametric and algorithmic modeling software combined with optimization techniques to enable process automation. These techniques allow the expansion of the number of intervals of the variables, as well as the increase of the number of variables under study, allowing the best design alternatives to be found without necessarily exploring each one individually (BRE; ROMAN; FACHINOTTI, 2020).

Some studies have used optimization techniques to find the best design solutions based on the variation of design parameters. Bichiou and Krarti (2011) conducted a study to optimize the HVAC system and the characteristics of the envelope of residential buildings in five American cities. Variables such as: solar orientation, shape, thermal transmittance of walls and roofs, infiltration rates, window-to-wall ratio (WWR), among others, were studied. The objective was to reduce life cycle costs and the results showed savings of 10 to $25 \%$, depending on the climate and the form of construction. Hamdy, Hasan and Siren (2011) selected three models of residential buildings and eight parameters of the envelope such as: thermal transmittance of walls and roof, types of windows, shadings, among others. The purpose of the optimization was to reduce greenhouse gas emissions and the cost of construction, as well as HVAC costs. When compared to the initial model, the optimization achieved $32 \%$ of $\mathrm{CO}_{2}$ reduction and $25 \%$ of savings in construction costs. Jin and Jeong (2014) used genetic algorithms to optimize the free form of a building in order to improve the thermal load. From Grasshopper's modeling, they obtained different shapes optimized for various cities and climatic zones around the world. Yu et al. (2015) used multi-objective optimization to improve energy efficiency and thermal comfort in a multifamily residential project in China. Variables such as orientation, area, number of floors, WWR, transmittance and thermal capacity of walls and roofs were studied. Ascione et al. (2016) used multi-objective optimization to minimize energy demand in summer and winter, without compromising thermal comfort. A nZEB residential model was used in four Mediterranean cities, where parameters related to the building envelope were studied. The results showed the difficulty to define the best solution for both summer and winter performances. Bre and Fachinotti (2017) used GA to enhance a single-family house typical of the Argentine coast. Variables such as roofing materials and walls, solar orientation, solar absorptance, dimensions and types of windows and solar shadings aimed at the thermal performance were studied. The results indicated an improvement of up to $95 \%$ in the thermal comfort of naturally ventilated rooms and up to $82 \%$ in artificially conditioned rooms. Zhang, Liu and Wang (2020) conducted an optimization of a residential project aiming at energy efficiency based on Grasshopper modeling. The researchers used parameters related to the shape and envelope such as ceiling height, room dimensions, WWR and thermal transmittance. The results indicated a reduction in thermal load per square meter of up to $18 \%$.

However, even today, most architectural projects are based mainly on the subjective experience of architects, which leads to inaccurate procedures in terms of thermal performance.

In recent years, however, computational advances have allowed the creation of new methods and tools that support the architectural design of more efficient buildings. Although there are several tools that aim to define the envelope together with the understanding of the climate, these tools are often underutilized or used in advanced stages of the design process.

Parametric modeling linked to optimization techniques shows great potential to achieve good levels of performance during the early stages of architectural design. This integration between methods and techniques allows the thermal performance to be significantly improved by changing the geometry and configuration of the building envelope, such as opaque materials, solar orientation, orientation and dimension of windows, dimension of solar shadings, among others.

In cases where the number of design alternatives is very large, it is necessary to automate this task. One solution is using simulation-based optimization (SBO) techniques that integrate building performance simulation with algorithmic optimization. Numerical optimization applications have been used since the 1980s and 1990s. However, most studies involving engineering problems have been developed since the 2000s (NGUYEN; REITER; RIGO, 2014). 
Mathematically, multi-objective optimization consists of obtaining a set of solutions that satisfy some restrictions and optimize (minimize or maximize) objective functions. The evaluation of feasible solutions then passes through the concept of Pareto Dominance, which affirms that the solution to a multi-objective optimization problem will be optimal if there is no other feasible solution that reduces one objective without increasing another. These solutions that overcome others are known as non-dominated solutions.

The function of the algorithms is to search among a wide range of design alternatives, those that contribute to generate the best solutions, forming the optimal set of Pareto (set of non-dominated solutions). A solution is non-dominated if there is not any other feasible solution that improves one objective without deteriorating at least one another (BRE; FACHINOTTI, 2017). In cases where the objectives are conflicting, they form a multidimensional set of solutions, called the Pareto Curve (when there are 2 objectives) or Pareto Front (when there are 3 or more objectives). Most studies are based on up to 2 objective-functions due to the complexity of the process and analysis. This way, the problem will not have a single optimal solution, but several almost optimal solutions. Finally, the researcher must decide how to determine the "optimal" solution among the Pareto set. Here, we proposed the use of a strategy based on the shortest distance between the Pareto solutions and the ideal point, as used by Bre and Fachinotti (2017), where (Equation 1):

$P_{\text {ideal }}=\left[\min \left(f_{1}\right) \min \left(f_{2}\right) \ldots \min \left(f_{n}\right)\right]$

In multi-objective optimization problems, this point is usually not reached due to the conflicting nature of the objectives. To determine the distance of a Pareto solution $\left(x^{o p t}\right)$ to the ideal point, Equation 2 must be used.

$d\left(x^{o p t}\right)=\sqrt{\left[f_{1}\left(x^{o p t}\right)-\min \left(f_{1}\right)\right]^{2}+\left[f_{2}\left(x^{o p t}\right)-\min \left(f_{2}\right)\right]^{2}}$

Figure 1 schematizes the Pareto curve, the ideal point and the final "optimal" solution for the problem of minimizing two conflicting objectives.

Although many Pareto optimizations have been developed, some optimization techniques aimed at solving architectural and engineering problems are more appropriate. Those that showed to be more robust are those based on bioinspired processes, which include genetic algorithms (GA). This is because the objective functions of this type of problem are usually non-linear and have discontinuities (ZHANG; LIU; WANG, 2020).

The GA principle is based on Darwin's Evolution Theory and can be explained in a very simple way (MAGNIER, 2008):

(a) first, an initial population is created randomly, in which each individual represents a feasible solution. These individuals are generated from a set of parameters (e.g. design variables);

(b) in each generation, couples of individuals (parents) create new solutions through mechanisms such as crossover and mutation (these new individuals are known as children);

(c) at the end of each generation, probable solutions are evaluated using the objective function defined in the study. The best solutions will be kept in the next generation according to the defined elitism rate; and

(d) steps 2 and 3 take place until the stopping criterion is reached (usually based on the number of generations or the population stagnation that better fits the objectives).

This paper aims to optimize design parameters of the geometry of social housing aiming at higher thermal performance of buildings in the city of Chapecó/SC, Brazil. The objective of these parameters is to define design guidelines to assist architects, in the early-design stages, in the definition of the most appropriate building envelope for this typology and the climate of the region.

\section{Method}

Nguyen, Reiter and Rigo (2014) divide a simulation-based optimization (SBO) in 3 main phases: preprocessing, processing and post-processing (Figure 2), each one composed by various tasks.

\section{Preprocessing}

The preprocessing phase of an SBO is outlined in Figure 3. Firstly, the parametric model of the building under study was developed, integrating form, material information, occupancy schedules, climate, among others. The optimization objectives were determined based on the climatic conditions of the city of Chapecó and the subject of study (naturally ventilated single-story house). Based on this, there were selected variables

44 Berleze, A. S.; Brasileiro, A. de B. H.; Silvoso, M. M. 
that could contribute to achieve these objectives. Finally, an optimization engine automated the process, exploring the range of variables in order to find the solutions that will best meet the objective functions.

\section{Figure 1 - Pareto curve diagram, ideal point and "optimal" solution to minimize two contradictory} objectives $\mathrm{f} 1$ and $\mathrm{f} 2$

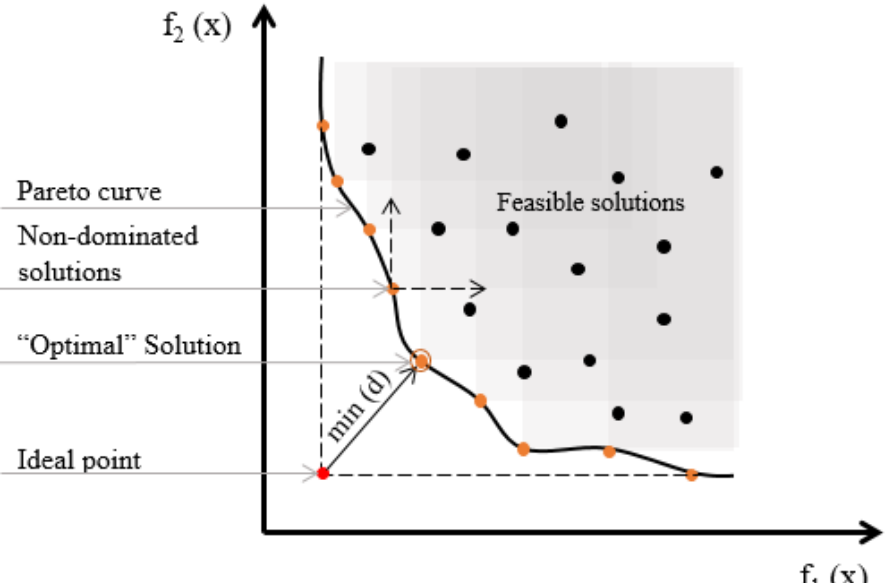

Source: adapted from Bre and Fachinotti (2017).

Figure 2 - Main phases of a building simulation-based optimization

\begin{tabular}{|c|c|}
\hline Phase & Major tasks \\
\hline 1. Preprocessing & $\begin{array}{l}\text { Formulation of the optimization problem: } \\
\text { - Computer building model } \\
\text { - Setting objective functions and constraints } \\
\text { - Selecting and setting design variables and constraints } \\
\text { - Coupling the optimization algorithm and the building simulation program }\end{array}$ \\
\hline 2. Processing/ optimization & $\begin{array}{l}\text { Selecting an appropriate optimization algorithm and its settings for the problem } \\
\text { Monitoring convergence } \\
\text { Controlling termination criteria } \\
\text { Detecting errors or simulation failures }\end{array}$ \\
\hline 3. Post-processing & $\begin{array}{l}\text { Interpreting optimization results } \\
\text { Verification and comparing optimization results with 'real' models } \\
\text { Presenting the results }\end{array}$ \\
\hline
\end{tabular}

Source: adapted from Nguyen, Reiter and Rigo (2014).

Figure 3 - Preprocessing phases

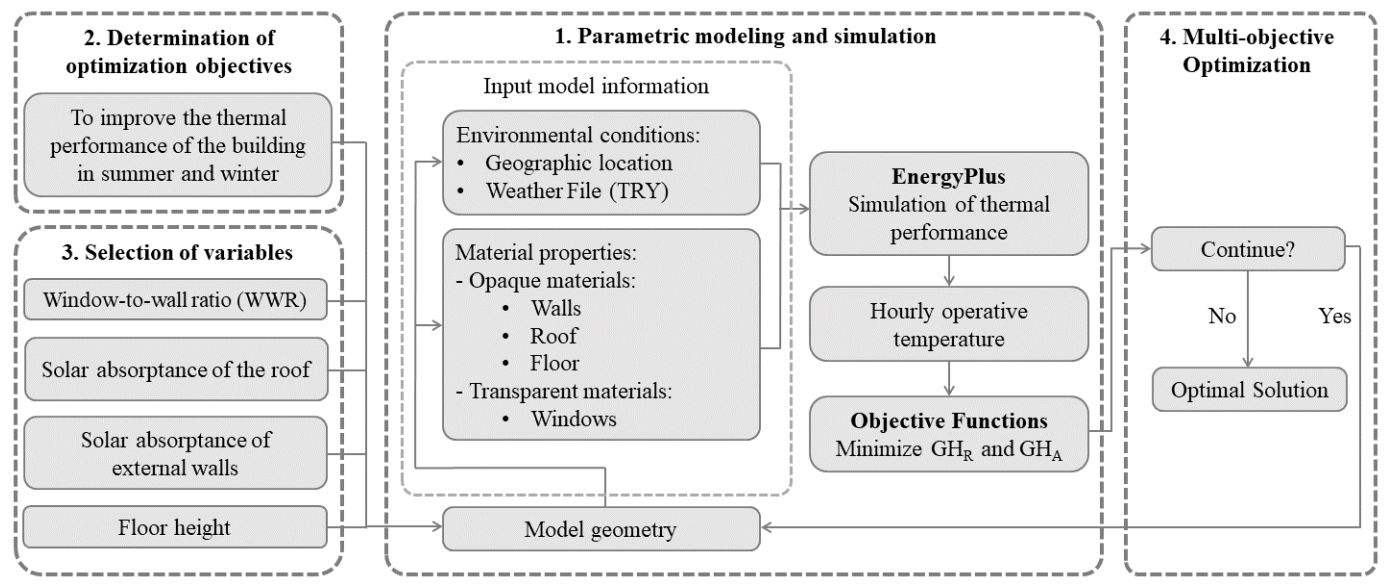




\section{Parametric modeling}

The parametric simulation model was done in the Rhinoceros V6.0 (RHINO3D, 2020), using the Grasshopper graphic editor. The Archsim plugin (SOLEMMA, 2020) was used to integrate the Grasshopper with EnergyPlus V8.4.0 (ENERGYPLUS, 2020), allowing the simulation of the models' thermal performance. This plugin integrates the formal characteristics of the building, the thermophysical characteristics of the materials and the schedules of use and occupancy to the weather file. From the EnergyPlus output data (hourly operative temperature of the long-stay rooms), The Grasshopper calculates the degree-hours of discomfort for cooling and heating. The function of the Octopus plugin is to serve as the optimization engine, to conduct multi-objective optimization and to apply evolutionary principles to parametric design and problem-solving. The tools used in the simulation-based optimization process are shown in Figure 4.

\section{Case study}

The study was carried out in the city of Chapecó, in the South Region of Brazil (with latitude 27.10S, longitude $52.61 \mathrm{~W}$ and altitude $670 \mathrm{~m}$ ). The city belongs to the Brazilian Bioclimatic Zone 3, according to Brazilian standard NBR 15220-3 (ABNT, 2005). According to the climatic normals (INSTITUTO NACIONAL..., 2020), the average temperatures vary from $22.9{ }^{\circ} \mathrm{C}$ during the hottest month (February) to $14.1{ }^{\circ} \mathrm{C}$ in the coldest month (June) and the minimum average temperatures are around $10{ }^{\circ} \mathrm{C}$, however absolute lows reach negative temperatures. According to the report generated in the AnalysisBio software, V2.2 (ANALYSISBIO, 2018), Chapecó presents 34\% of the year in hygrothermal comfort and $66 \%$ of discomfort hours, $43 \%$ of the time is due to cold and $23 \%$ is due to heat. These numbers show ventilation and shading strategies in summer and passive solar heating and thermal inertia for heating are necessary, in addition to artificial heating in the coldest hours of the year.

For this study, three models of social housing were analyzed: the first corresponds to a typical building of the PMCMV (Figure 5), existing on the site and here named as the base model, and two other models were proposed based on the doctoral dissertation of one of the authors (BERLEZE, 2020).

The three models refer to a single-story house with the same architectural set: 2 bedrooms, 1 bathroom, 1 kitchen, 1 living/dining room, as well as the same solar orientation.

The differences between the base model and the proposed models are related to the useful areas and typologies: the base model represents a typology of a two-family house, composed of 2 housing units. The useful area of each unit is $32.07 \mathrm{~m}$, totaling $64.15 \mathrm{~m}$ of the building.

The proposed models "A" and "B" represent single-family detached houses. The dimensions of the long-stay room (LSR 1 ) were varied according to a study conducted in Berleze (2020). Model " $\mathrm{A}$ " has a narrow façade and greater depth in plan (Figure 6), totaling a variable useful area from $45.60 \mathrm{~m}$ to $48.80 \mathrm{~m}$. Model "B" has a wide façade and less depth in plan (Figure 7), in addition to a variable useful area from $47.25 \mathrm{~m}$ to $48.70 \mathrm{~m}$. In addition, another difference is that in the proposed models the service area is internal to the building, while in the base model it is not considered.

\section{Selection of design variables}

In the analysis of the base model only the performance simulation was used (without optimizing any parameters). For this, the real characteristics of the envelope (according to the project specifications) were considered, as shown in Table 1. In addition, a study previously carried out (BERLEZE, 2020), which analyzed different types of walls and roofs, ceiling height and absorptance of the envelope materials, indicated the materials presented in Table 2 as the most suitable for this typology and location. As a result, the envelope materials, the ceiling height and the absorptance of the roof were kept fixed in the simulations involving models " $\mathrm{A}$ " and " $\mathrm{B}$ ".

The proposed models " $\mathrm{A}$ " and " $\mathrm{B}$ " involved simulation-based optimization techniques (SBO). Therefore, in model "A", 15 continuous and discrete, dependent and independent variables were used, as shown in Table 3 and Figure 6. The same applies to Model "B", with 14 variables used, as shown in Table 4 and Figure 7.

${ }^{1}$ Long-stay room (e.g. bedrooms and living rooms). 
Figure 4 - Scheme of integration between software and plugins used

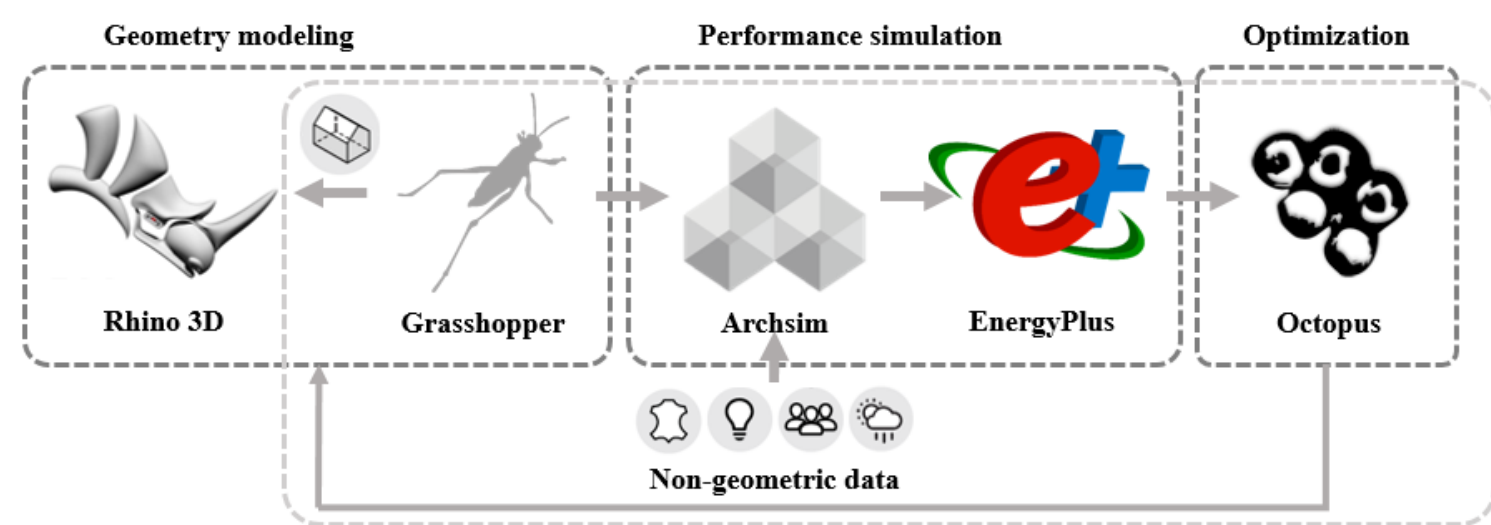

Figure 5 - Base model of the building - Two-family house

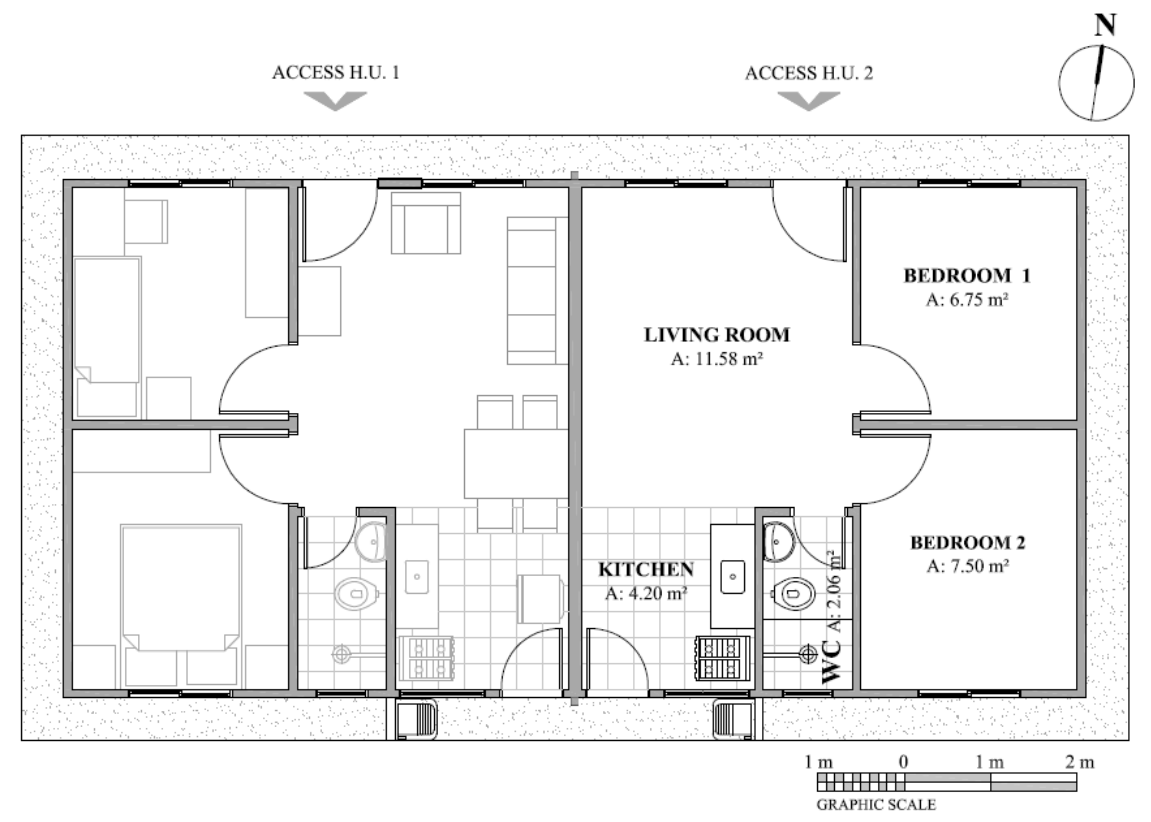

Table 1 - Actual characteristics of the base model

\begin{tabular}{|c|c|c|}
\hline Variable & \multicolumn{2}{|c|}{ Characteristic } \\
\hline Solar orientation & North (main façade) & $9^{\circ}$ (according to project) \\
\hline Ceiling height & & $\mathrm{h}=2.50 \mathrm{~m}$ \\
\hline \multirow{4}{*}{ External wall type } & \multirow{4}{*}{$\begin{array}{l}\text { Ceramic brick } 8 \text { holes }(9 \mathrm{~cm})+ \\
\text { internal plaster }(1 \mathrm{~cm})+\text { external } \\
\text { plaster }(1 \mathrm{~cm})\end{array}$} & U-value $^{1}=2.64 \mathrm{~W} / \mathrm{m} \mathrm{K}$ \\
\hline & & $\mathrm{TC}^{2}=102 \mathrm{~kJ} / \mathrm{m} \mathrm{K}$ \\
\hline & & $\alpha=0.4$ \\
\hline & & $\varphi_{\mathrm{PAR}}=2.7$ hours \\
\hline \multirow{4}{*}{ Roof type } & \multirow{4}{*}{$\begin{array}{l}\text { Fiber cement }(8 \mathrm{~mm})+\text { inner tube }> \\
5 \mathrm{~cm}+\text { PVC lining }(1 \mathrm{~cm})\end{array}$} & $\mathrm{U}$-value $=1.76 \mathrm{~W} / \mathrm{m} \mathrm{K}$ \\
\hline & & $\mathrm{TC}=15 \mathrm{~kJ} / \mathrm{m} \mathrm{K}$ \\
\hline & & $\alpha=0.8$ \\
\hline & & $\varphi_{\mathrm{COB}}=0.6$ hours \\
\hline Glass type & Common $3 \mathrm{~mm}$ & $\begin{array}{l}\text { U-value }=5.7 \mathrm{~W} / \mathrm{m} \mathrm{K} \\
\mathrm{SF}^{3}=0.87\end{array}$ \\
\hline $\begin{array}{l}\text { Windows the living room } \\
\text { and bedrooms) }\end{array}$ & \multirow{2}{*}{$\begin{array}{l}\text { Infiltration rate }=0.01 \mathrm{~kg} / \mathrm{s} . \mathrm{m} \\
\text { Effective ventilation } \mathrm{span}=40 \% \\
\text { Discharge coefficient }=0.60\end{array}$} & $\mathrm{~A}=1.44 \mathrm{~m}$ \\
\hline Kitchen window & & $\mathrm{A}=0.8 \mathrm{~m}$ \\
\hline
\end{tabular}

Note: ${ }^{1}$ Thermal Transmittance $\left[\mathrm{W} / \mathrm{m}^{2} \mathrm{~K}\right]$; ${ }^{2}$ Thermal Capacity $\left[\mathrm{kJ} / \mathrm{m}^{2} \mathrm{~K}\right]$; and ${ }^{3}$ Solar Factor. 
Table 2 - Characteristics common to models " $A$ " and "B"

\begin{tabular}{|c|c|c|}
\hline Variable & \multicolumn{2}{|c|}{ Characteristic } \\
\hline Solar orientation & North (main façade) & $9^{\circ}$ (according to project) \\
\hline Ceiling height & & $\mathrm{h}=2.50 \mathrm{~m}$ \\
\hline \multirow{3}{*}{ External wall type } & \multirow{3}{*}{$\begin{array}{l}\text { Ceramic brick } 9 \text { holes }(14 \mathrm{~cm})+\text { internal } \\
\text { plaster }(2.5 \mathrm{~cm})+\text { external plaster }(2.5)\end{array}$} & $\mathrm{U}$-value $=1.93 \mathrm{~W} / \mathrm{m} \mathrm{K}$ \\
\hline & & $\mathrm{TC}=189 \mathrm{~kJ} / \mathrm{m} \mathrm{K}$ \\
\hline & & $\varphi_{\mathrm{PAR}}=4.6$ hours \\
\hline \multirow{4}{*}{ Roof type } & \multirow{4}{*}{$\begin{array}{l}\text { Metallic tile with PU }(4.2 \mathrm{~cm})+\text { inner } \\
\text { tube }>5 \mathrm{~cm}+\text { concrete } \mathrm{slab}(10 \mathrm{~cm})\end{array}$} & $\mathrm{U}$-value $=0.55 \mathrm{~W} / \mathrm{m} \mathrm{K}$ \\
\hline & & $\mathrm{TC}=230 \mathrm{~kJ} / \mathrm{m} \mathrm{K}$ \\
\hline & & $\varphi_{\mathrm{COB}}=12.6$ hours \\
\hline & & $\alpha=0.2$ \\
\hline Glass type & Common $3 \mathrm{~mm}$ & $\begin{array}{l}\text { U-value }=5.7 \mathrm{~W} / \mathrm{m} \mathrm{K} \\
\mathrm{SF}=0.87\end{array}$ \\
\hline
\end{tabular}

Table 3 - Variables and intervals used in the optimization of Model " $A$ "

\begin{tabular}{|c|c|c|c|c|c|c|}
\hline \multicolumn{2}{|r|}{ Variables } & \multirow{2}{*}{$\frac{\text { Un. }}{-}$} & \multirow{2}{*}{$\begin{array}{c}\text { Limit value } \\
0.2 \text { to } 0.8\end{array}$} & \multirow{2}{*}{$\frac{\text { Interv }}{\text { Free }}$} & \multicolumn{2}{|c|}{ Variable type } \\
\hline 1 & Wall Absorptance & & & & Continuous & Independent \\
\hline \multirow{2}{*}{2} & $\mathrm{X}$ (bedroom width) & $\mathrm{m}$ & 3.0 to 3.30 & 0.05 & Discrete & Independent \\
\hline & Y (length of bedrooms) & $\mathrm{m}$ & 3.30 to 3.0 & 0.05 & Discrete & X-dependent \\
\hline 3 & X2 (social width) & $\mathrm{m}$ & 2.55 to 2.75 & 0.05 & Discrete & Independent \\
\hline 4 & Y2 (living room length) & $\mathrm{m}$ & 2.45 to 2.65 & 0.05 & Discrete & Independent \\
\hline \multirow{2}{*}{5} & Y3 (dinner length) & $\mathrm{m}$ & 2.20 to 2.30 & 0.05 & Discrete & Independent \\
\hline & Y4 (kitchen length) & $\mathrm{m}$ & 1.95 to 2.75 & 0.05 & Discrete & Y3- Dependent \\
\hline 6 & $\begin{array}{l}\text { Bedroom } 1 \text { Window } \\
\text { Solar orientation }\end{array}$ & - & $\mathrm{N}$ or $\mathrm{E}$ & - & - & Independent \\
\hline 7 & Bedroom $1 \mathrm{WWR}^{1}$ & $\%$ & 0.45 to 0.60 & Free & Continuous & $\begin{array}{c}\text { Dependent on variables } \\
6 \text { and } 2(\mathrm{X} \text { or } \mathrm{Y})\end{array}$ \\
\hline 8 & $\begin{array}{l}\text { Bedroom } 2 \text { Window } \\
\text { Solar orientation }\end{array}$ & - & $\mathrm{E}$ or $\mathrm{S}$ & - & - & Independent \\
\hline 9 & Bedroom $2 \mathrm{WWR}^{1}$ & $\%$ & 0.45 to 0.60 & Free & Continuous & $\begin{array}{c}\text { Dependent on variables } \\
8 \text { and } 2(\mathrm{X} \text { or } \mathrm{Y})\end{array}$ \\
\hline 10 & $\begin{array}{l}\text { Living room Window } \\
\text { Solar orientation }\end{array}$ & - & $\mathrm{N}$ or $\mathrm{W}$ & - & - & Independent \\
\hline 11 & Living room $\mathrm{WWR}^{1}$ & $\%$ & 0.45 to 0.60 & Free & Continuous & $\begin{array}{c}\text { Dependent on variables } \\
10 \text { and ( } 3 \text { or } 4)\end{array}$ \\
\hline 12 & Dining Room WWR ${ }^{1}$ & $\%$ & 0.40 to 0.60 & Free & Continuous & Independent \\
\hline 13 & Kitchen $W_{W R}^{2}$ & $\%$ & 0.40 to 0.45 & Free & Continuous & Independent \\
\hline 14 & $\begin{array}{l}\text { Bd (Solar shading } \\
\text { Bedrooms Depth) }\end{array}$ & $\mathrm{m}$ & 0 to 1.0 & Free & Continuous & Independent \\
\hline 15 & $\begin{array}{l}\text { Bs (Solar shading } \\
\text { Social Depth) }\end{array}$ & $\mathrm{m}$ & 0 to 1.0 & Free & Continuous & Independent \\
\hline
\end{tabular}

Note: ${ }^{1}$ Window to wall ratio. 
Figure 6 - Model “A" - Single-family house

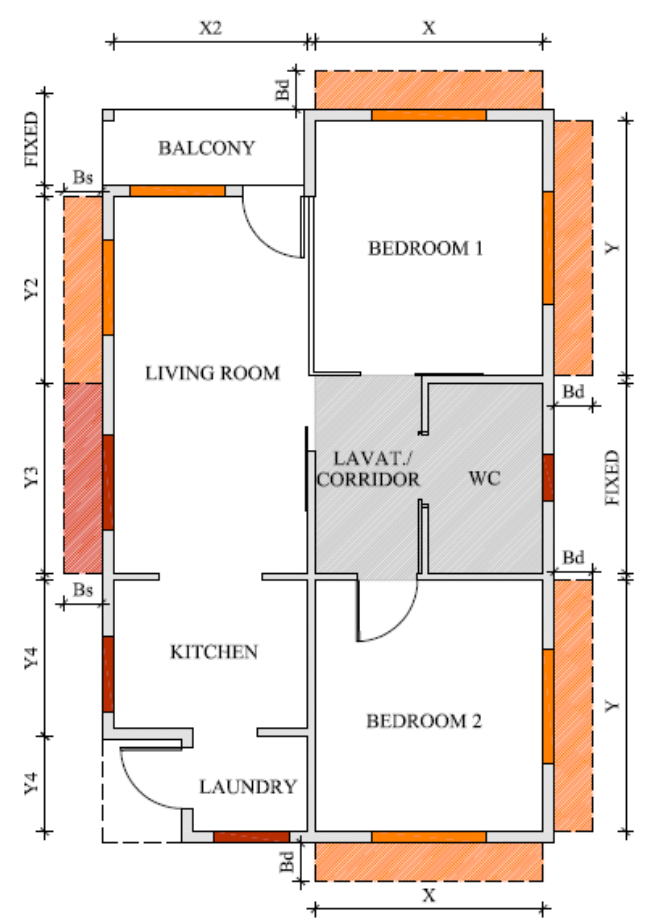

Figure 7 - Model “B” - Single-family house

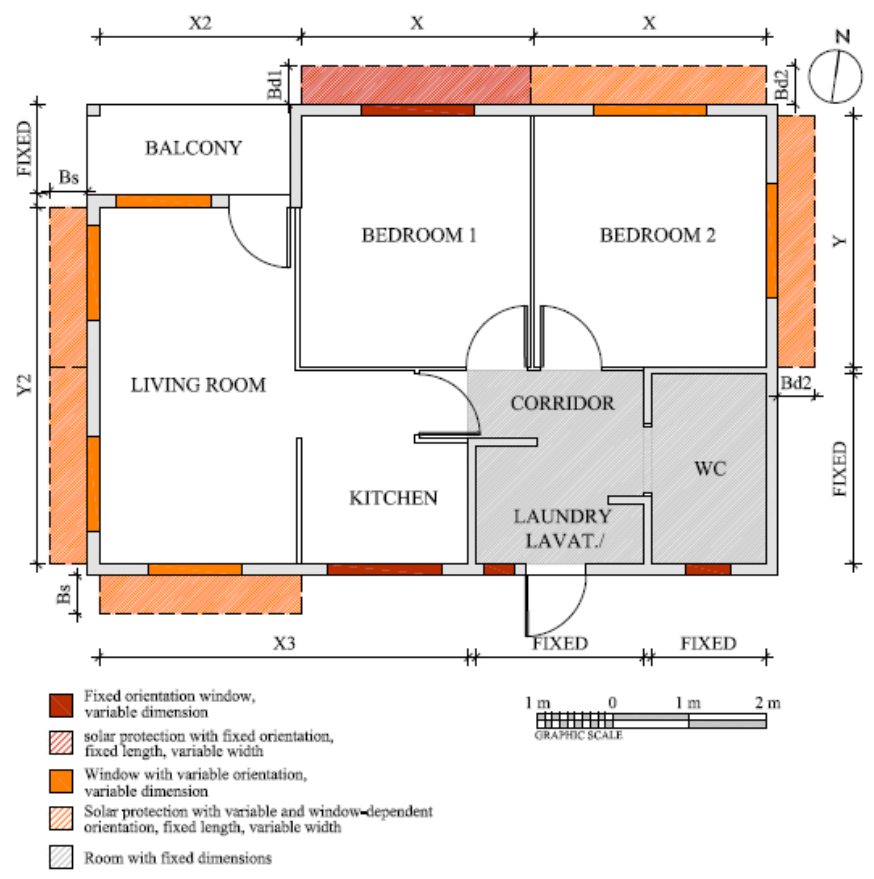


Table 4 - Variables and intervals used in the optimization of Model "B"

\begin{tabular}{|c|c|c|c|c|c|c|}
\hline \multicolumn{2}{|r|}{ Variables } & \multirow{2}{*}{$\frac{\text { Un. }}{-}$} & \multirow{2}{*}{$\frac{\text { Limit value }}{0.2 \text { to } 0.8}$} & \multirow{2}{*}{$\frac{\text { Interv }}{\text { Free }}$} & \multicolumn{2}{|c|}{ Variable type } \\
\hline 1 & Wall Absorptance & & & & Continuous & Independent \\
\hline \multirow{2}{*}{2} & X (bedroom width) & $\mathrm{m}$ & 3.0 to 3.30 & 0.05 & Discrete & Independent \\
\hline & Y (length of bedrooms) & $\mathrm{m}$ & 3.30 to 3.0 & 0.05 & Discrete & X-dependent \\
\hline 3 & X2 (social width) & $\mathrm{m}$ & 2.55 to 2.75 & 0.05 & Discrete & Independent \\
\hline \multirow[b]{2}{*}{-} & Y2 (social length) & $\mathrm{m}$ & 4.40 to 4.70 & 0.05 & Discrete & Independent \\
\hline & X3 (kitchen length) & $\mathrm{m}$ & 4.80 to 5.60 & 0.05 & Discrete & $\mathrm{X}$ and X2-Dependent \\
\hline 4 & Bedroom 1 WWR ${ }^{2}$ & $\%$ & 0.45 to 0.60 & Free & Continuous & Independent \\
\hline 5 & $\begin{array}{l}\text { Bedroom } 2 \text { Window Solar } \\
\text { orientation }\end{array}$ & - & $\mathrm{N}$ or $\mathrm{E}$ & - & - & Independent \\
\hline 6 & Bedroom $2 \mathrm{WWR}^{1}$ & $\%$ & 0.45 to 0.60 & Free & Continuous & $\begin{array}{c}\text { Dependent on variables } \\
5 \text { and } 2(\mathrm{X} \text { or } \mathrm{Y})\end{array}$ \\
\hline 7 & $\begin{array}{l}\text { Living room Window } \\
\text { Solar orientation }\end{array}$ & - & $\mathrm{N}$ or $\mathrm{W}$ & - & - & Independent \\
\hline 8 & Living room $\mathrm{WWR}^{1}$ & $\%$ & 0.45 to 0.60 & Free & Continuous & $\begin{array}{c}\text { Dependent on variables } \\
7 \text { and } 3 \\
\end{array}$ \\
\hline 9 & $\begin{array}{l}\text { Dining room Window } \\
\text { Solar orientation }\end{array}$ & - & $\mathrm{W}$ or $\mathrm{S}$ & - & - & Independent \\
\hline 10 & Dining Room WWR ${ }^{1}$ & $\%$ & 0.40 to 0.60 & Free & Continuous & Independent \\
\hline 11 & Kitchen WWR $^{1}$ & $\%$ & 0.40 to 0.45 & Free & Continuous & Independent \\
\hline 12 & $\begin{array}{l}\text { Bd1 (Solar shading } \\
\text { Bedroom } 1 \text { Depth) }\end{array}$ & $\mathrm{m}$ & 0 to 1.0 & Free & Continuous & Independent \\
\hline 13 & $\begin{array}{l}\text { Bd2 (Solar shading } \\
\text { Bedroom } 2 \text { Depth) }\end{array}$ & $\mathrm{m}$ & 0 to 1.0 & Free & Continuous & Independent \\
\hline 14 & $\begin{array}{l}\text { Bs (Solar shading } \\
\text { Social Depth) }\end{array}$ & $\mathrm{m}$ & 0 to 1.0 & Free & Continuous & Independent \\
\hline
\end{tabular}

The solar orientation of some windows may vary, and may be on one or the other façade. An external horizontal solar shading in all windows of the long-stay rooms was also proposed, so that the existence of shading is linked to the position of that window.

The internal gains related to people, lighting and equipment, patterns of use and occupancy and natural ventilation were defined according to the RTQ-R ${ }^{2}$ simulation method (INSTITUTO, 2012). For the calculation of natural ventilation, the EnergyPlus Airflow Network ${ }^{3}$ module was used.

The pattern of use of natural ventilation was configured through the strategy of automatic control, by temperature. The pattern that controls the opening of the windows enables its opening whenever the ambient air temperature $\left(T_{\text {int }}\right)$ is equal to or higher than the thermostat temperature $\left(T_{\text {int }} \geq T_{\text {Thermostat }}\right)$ and at the same time that the ambient air temperature is higher than the external temperature $\left(T_{\text {int }} \geq T_{\text {ext }}\right)$. Natural ventilation was configured as available all year round, with an operating temperature setpoint ( $\mathrm{T}_{\text {Thermostat }}$ equal to $20^{\circ} \mathrm{C}$ );

The effective ventilation span was configured according to the window model from the Annex II of the RTQ-R (INSTITUTO..., 2012), which corresponds to $40 \%$ for sliding and tilting windows and $90 \%$ for doors. The discharge coefficient was defined as 0.60 for windows and doors (INSTITUTO..., 2012).

Ground temperatures were calculated using the EnergyPlus software Slab.

For building performance simulations, the whole year (8760 hours) was considered using the TRY (Test Reference Year) climate file of Chapecó (BERLEZE, 2020).

${ }^{2}$ It is known that the patterns of use and occupation directly affect the thermal performance of buildings and that they have a questionable degree of uncertainty, especially in relation to their generalization in a country with as many cultural and environmental differences as Brazil. Therefore, although these data were used in the study, it is understood that they may not correspond to the local reality.

${ }^{3}$ Airflow Network is the airflow calculation model used in models naturally ventilated in EnergyPlus. The user can choose not to calculate wind pressure coefficients. In this case, the EnergyPlus software uses the equation of Swami and Chandra (1988) for small buildings. 


\section{Definitions of the objective-functions}

For the optimization process two objective functions were created. The first consists in the calculation of degree-hours for cooling, based on the RTQ-R simulation method (INSTITUTO..., 2012) (Equation 3). According to the RTQ-R, degree-hours (GH) is an indicator of the thermal performance of the envelope from naturally ventilated buildings, which represents the thermal discomfort caused by a specific building. The Regulation only evaluates summer performance by this method; winter performance is evaluated by the consumption of heating (AC) using an HVAC system.

However, it was previously verified by Berleze (2020) that the low income buildings under study are predominantly naturally ventilated, not using any artificial systems. Due to this, the thermal performance of the building during the winter did not follow the RTQ-R methodology, but the one of degree-hours for heating, as shown in Equation 4, based on Sorgato (2009).

$G H_{R}=\sum_{i=0}^{8760} T_{i}-26^{\circ} \mathrm{C}$, if $T_{i}>26^{\circ} \mathrm{C}$ Eq. 3

$G H_{A}=\sum_{i=0}^{8760} 18^{\circ} \mathrm{C}-T_{i}$, if $T_{i}<18^{\circ} \mathrm{C}$ Eq. 4

Where:

$\mathrm{GH}_{\mathrm{R}}$ is the indicator of degree-hours for cooling of the long-stay rooms $\left({ }^{\circ} \mathrm{Ch}\right)$;

$\mathrm{GH}_{\mathrm{A}}$ is the indicator of degree-hours for heating up of the long-stay rooms $\left({ }^{\circ} \mathrm{Ch}\right)$;

$\mathrm{T}_{\mathrm{i}}$ are the hourly operative temperatures of the long-stay rooms $\left({ }^{\circ} \mathrm{C}\right)$; and

$i$ is each one of the 8760 hours of the year (hour);

The base temperature for calculating degree-hours for cooling is $26^{\circ}$ and for degree-hours for heating is $18^{\circ}$.

In all cases, the closer to zero the degree-hours results are, the greater the thermal comfort indicator for summer (degree-hours for cooling) and winter (degree-hours for heating) situations, as well as for the whole year.

The hourly operative temperatures of the long-stay rooms (bedrooms and living room/kitchen) were the output data extracted from each EnergyPlus simulation. From these data, using equations modeled in the Grasshopper, firstly, the degree-hours for cooling and heating of each one of the long-stay rooms were calculated and later, the degree-hours of the building as a whole, through the weighted averages by the areas of these rooms, were also calculated.

\section{Processing/Optimization}

The processing stage consists of the optimization itself. As stated before, a GA is based on the principle of species evolution and, therefore, it evolves through mechanisms such as crossover and mutation, and also depends on definitions such as population size, number of generations and elitism rate to describe how the process will evolve.

The Octopus, the optimization engine used in this study, works with the genetic algorithms SPEA-2 (ZITZLER; LAUMANNS; THIELE, 2001) and HypE (BADER; ZITZLER, 2008), the last one being highly efficient in solving multi-objective problems as aimed in this study. In addition, this plugin allows the setting of the parameters related to the GA, such as: population size, number of generations, elitism rate, crossover rate, mutation probability and mutation rate, each of which directly affects the optimization process. Figure 8 presents the definition of each available parameter and the indication of some values used in similar works.

In a previous work, Berleze (2020) evaluated the convergence process with different configurations of the genetic algorithm, and the configurations shown in Table 5 were more adequate.

It is important to clarify that the first time the process is conducted, it is not possible to know how much the genetic algorithm (GA) will be able to advance, finding the best solutions. Thus, the tendency is to allow the process to run for more generations until it is guaranteed that there will be no better results after that, which means that there will have been a convergence of the results. The stopping criterion was based on the convergence of the solutions by observing the results of the Pareto set, the graphs generated by the Octopus, as well as the density of the distribution of the points along the Pareto curve. In the study previously conducted, the convergence occurred approximately in the 60th generation. 
Figure 8 - GA available parameters for configuration

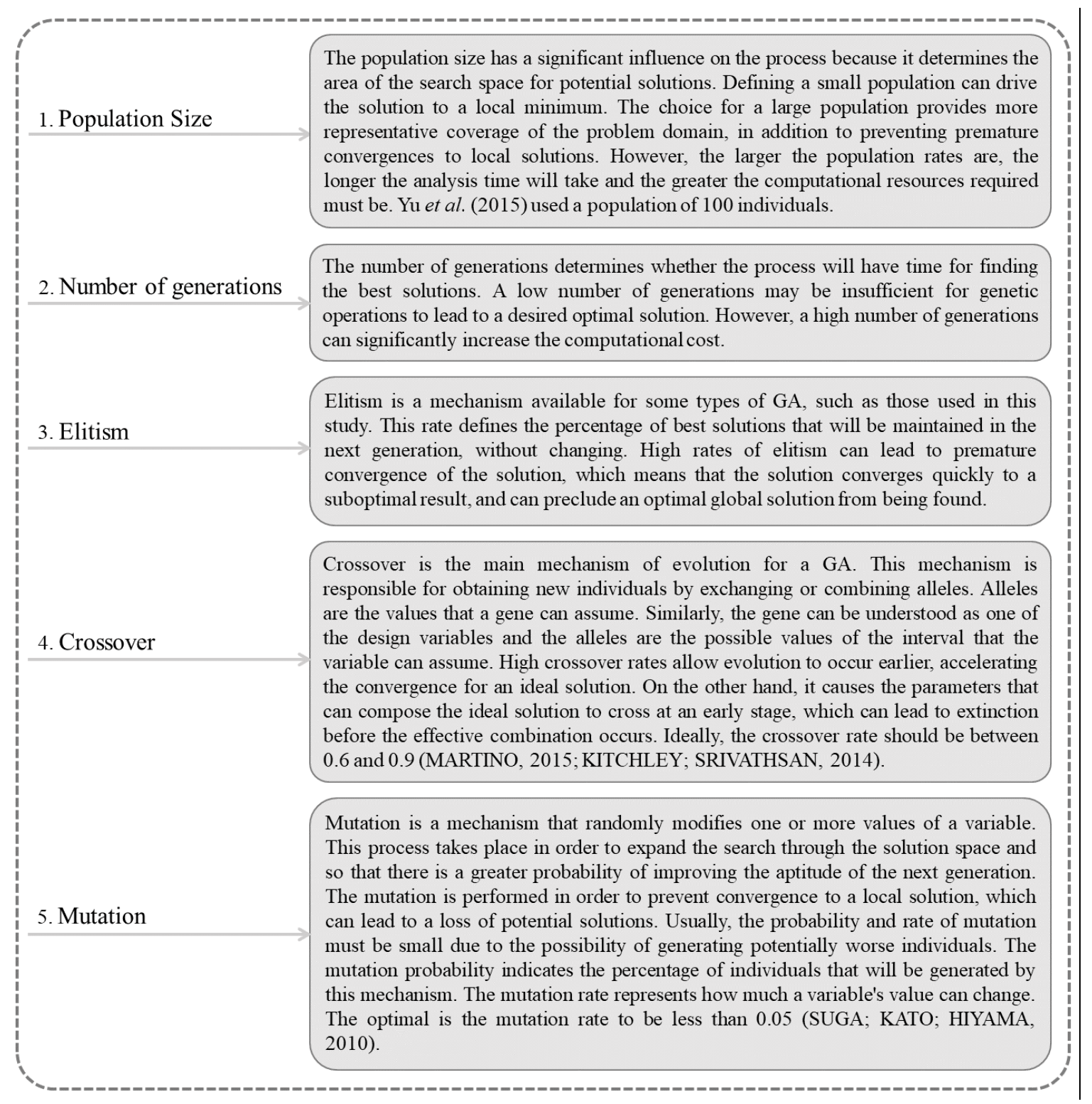

Table 5 - Configuration of the parameters of the genetic algorithm

\begin{tabular}{c|c|c|c|c|c}
\hline Elitism & Mutation Probabil. & Mutation Rate & Crossover & Population & GA \\
\hline 0.1 & 0.02 & 0.02 & 0.90 & 100 & $\mathrm{HypE}$ \\
\hline
\end{tabular}

\section{Post-processing}

The post-processing phase or analysis of results is the most difficult one in an SBO, requiring many hours of work. The disadvantage of the Octopus compared to other optimization engines is that the visualization, manipulation and analysis of the best solutions has not yet been developed in an attractive manner. As a result, most studies involving these methods and this plugin specifically ends up analyzing the generations on time, without being able to analyze the entire convergence process or verify the occurrence of errors.

In this research, the importation of all non-dominated solutions of all generations was prioritized, which was only possible and viable after the creation of Macros in Excel that automated the whole process of importing this data. In addition, the data organization also required the use of advanced functions and the creation of filters in Excel. 


\section{Results and discussion}

This section summarizes the results of the simulation-based optimization of two proposed models "A" and "B", from the variation of 15 and 14 design parameters referring to the geometry of low-income singlefamily homes. In addition, it compares the results with the building performance simulation of the existing building (base model) at Loteamento Expoente, in Chapecó/SC.

\section{Base model}

The base model corresponds to the actual building at the study site, consisting of the closing configurations according to Table 1 and Table 6 . This model resulted in heat discomfort $\left(\mathrm{GH}_{\mathrm{R}}\right)$ of $4,114{ }^{\circ} \mathrm{Ch}$ and cold discomfort $\left(\mathrm{GH}_{\mathrm{A}}\right)$ of $8,555^{\circ} \mathrm{Ch}$. This model is represented in Figure 9.

At this stage, the EnergyPlus output data (outside air temperature and operative temperature of the long-stay rooms) were analyzed. Figure 10 represents the outdoor air temperature and the building's operative temperature with hourly data over a year. The comfort range (between $18{ }^{\circ} \mathrm{C}$ and $26^{\circ} \mathrm{C}$ ) was also delimited.

Table 6 - Configuration of the variables resulting from the base model

\begin{tabular}{c|c|c|c|c|c|c|c|c}
\hline GHR & GH $_{\mathbf{A}}$ & $\begin{array}{c}\text { Ceiling } \\
\text { height } \\
(\mathbf{m})\end{array}$ & $\begin{array}{c}\text { Window } \\
\text { bedroom 1 } \\
\mathbf{m}^{\mathbf{2}}(\mathbf{W W R})\end{array}$ & $\begin{array}{c}\text { Window } \\
\text { bedroom 2 } \\
\mathbf{m}^{\mathbf{2}}(\mathbf{W W R})\end{array}$ & $\begin{array}{c}\text { Window } \\
\text { living room } \\
\mathbf{m}^{\mathbf{2}}(\mathbf{W W R})\end{array}$ & $\begin{array}{c}\text { Window } \\
\text { kitchen } \\
\mathbf{m}^{\mathbf{2}}(\mathbf{W W R})\end{array}$ & $\begin{array}{c}\text { Roof } \\
\text { Abs. }\end{array}$ & $\begin{array}{c}\text { Wall } \\
\text { Abs. }\end{array}$ \\
\hline 4,114 & 8,555 & 2.5 & $1.44(0.5)$ & $1.44(0.5)$ & $1.44(0.5)$ & $0.8(0.55)$ & 0.8 & 0.4 \\
\hline
\end{tabular}

Figure 9 - Representation of the base model

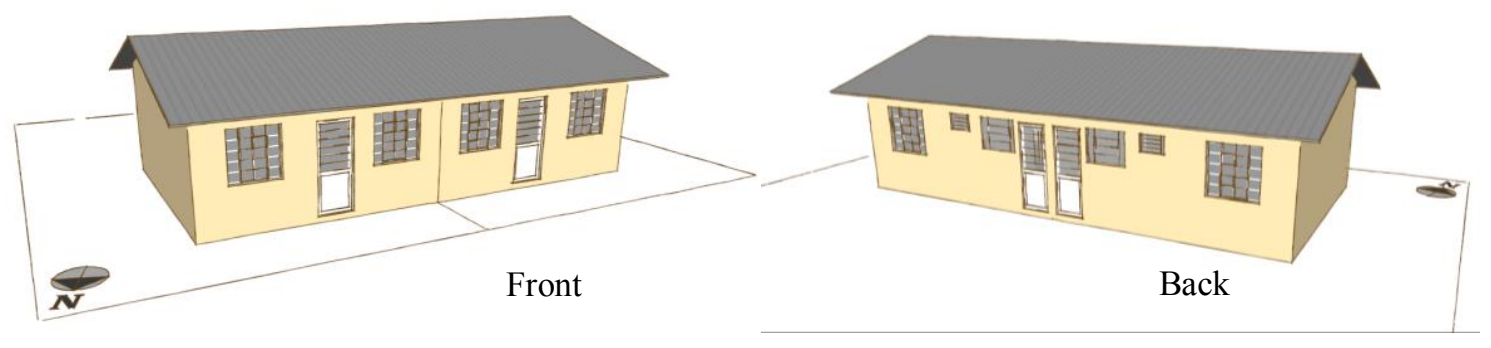

Figure 10 - External air temperature $\mathrm{x}$ operating temperature of the building

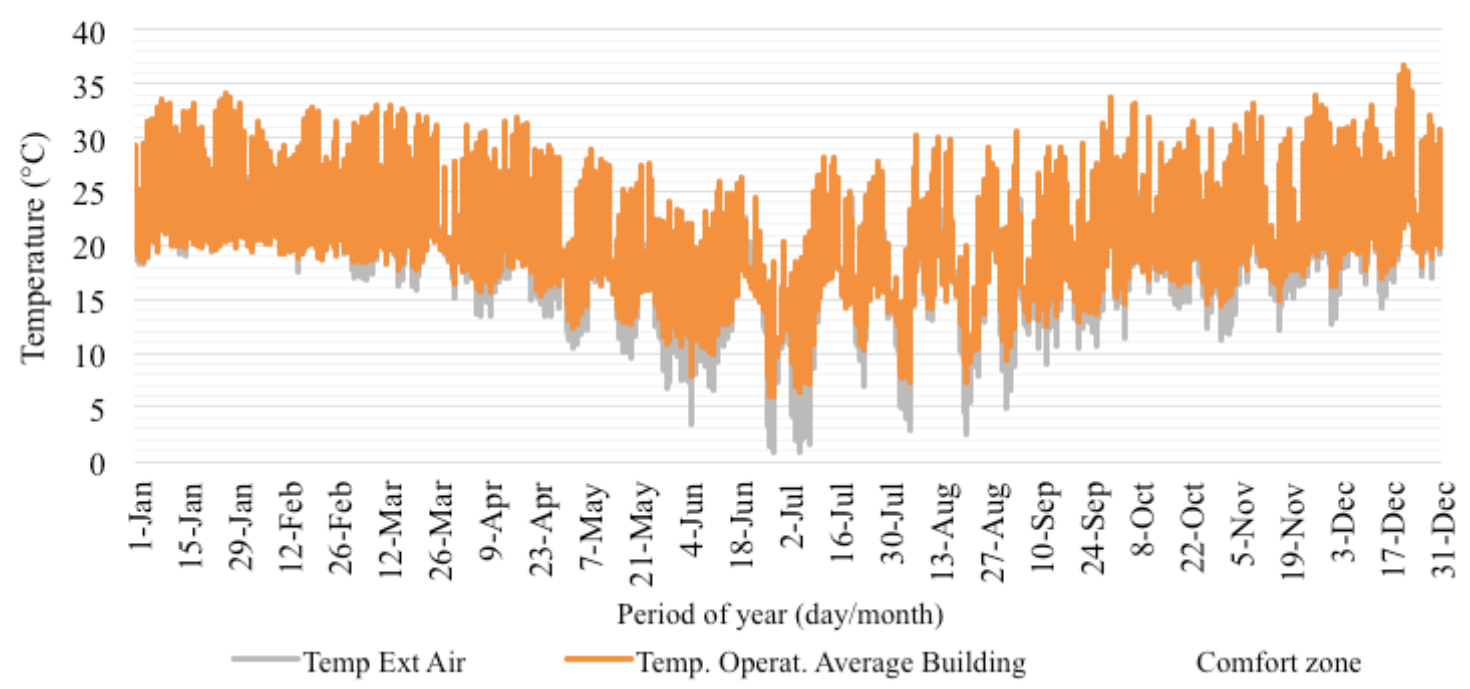

Multi-objective optimization of the geometry of single-family housing to improve thermal performance 
The temperatures above the comfort range present an average of $2.8^{\circ} \mathrm{C}$, spread over 1,440 hours, which represents $16 \%$ of the year in thermal discomfort due to heat. Regarding temperatures below the comfort range, they have an average of $3.2{ }^{\circ} \mathrm{C}$ spread over 2,642 hours, which represents about $30 \%$ of thermal discomfort due to cold throughout the year. Heat discomfort, therefore, in addition to occurring less frequently, also presents a smaller temperature difference in relation to the comfort range than cold discomfort, which indicates, together with the bioclimatic analysis, that it is more easily solved than cold discomfort.

The lowest temperatures occur in bedroom 1 of both housing units (two-family house), reaching $5.6{ }^{\circ} \mathrm{C}$ in winter. The highest temperatures were observed in the living room/kitchen of both units, in bedroom 2 of house 2 , and in bedroom 1 of house 1 , reaching $36.6^{\circ} \mathrm{C}$ in summer.

It is noticed, therefore, that the existing dwelling does not provide thermal comfort to residents. Since the low use of electromechanical systems for conditioning in this location has already been verified, there should be greater concern in relation to the performance of the building and the thermal comfort of the residents.

\section{Proposed Models "A" a "B"}

The purpose of the optimizations performed in this study was to improve the thermal performance of the naturally ventilated dwellings by minimizing the degree-hours of discomfort for cooling and heating. The optimizations of the "A" and "B" models resulted in 2,280 and 3,750 Pareto solutions, respectively, both conducted for 60 generations each. Figures 11 and 12 show the optimal Pareto set for each optimization.

The "A" model presented $\mathrm{GH}_{\mathrm{R}}$ values that varied from $141{ }^{\circ} \mathrm{Ch}$ (the best thermal performance for the hot period) to $1,481^{\circ} \mathrm{Ch}$ (the worst performance for the hot period among non-dominated solutions). This same model showed $\mathrm{GH}_{\mathrm{A}}$ values that ranged from $5,410{ }^{\circ} \mathrm{Ch}$ (the best thermal performance for the cold period) to $7,582{ }^{\circ} \mathrm{Ch}$ (the worst performance for the cold period among non-dominated solutions).

The " $\mathrm{B}$ " model, on the other hand, presented $\mathrm{GH}_{\mathrm{R}}$ values that varied from $90{ }^{\circ} \mathrm{Ch}$ (the best thermal performance for the hot period) to $1,116{ }^{\circ} \mathrm{Ch}$ (the worst performance for the hot period among the nondominated solutions). This model showed $\mathrm{GH}_{\mathrm{A}}$ values that ranged from $4,383{ }^{\circ} \mathrm{Ch}$ (the best thermal performance for the cold period) to $6,579{ }^{\circ} \mathrm{Ch}$ (the worst performance for the cold period among nondominated solutions).

Figure 11 - Set of Pareto-optimal solutions of the model "A"

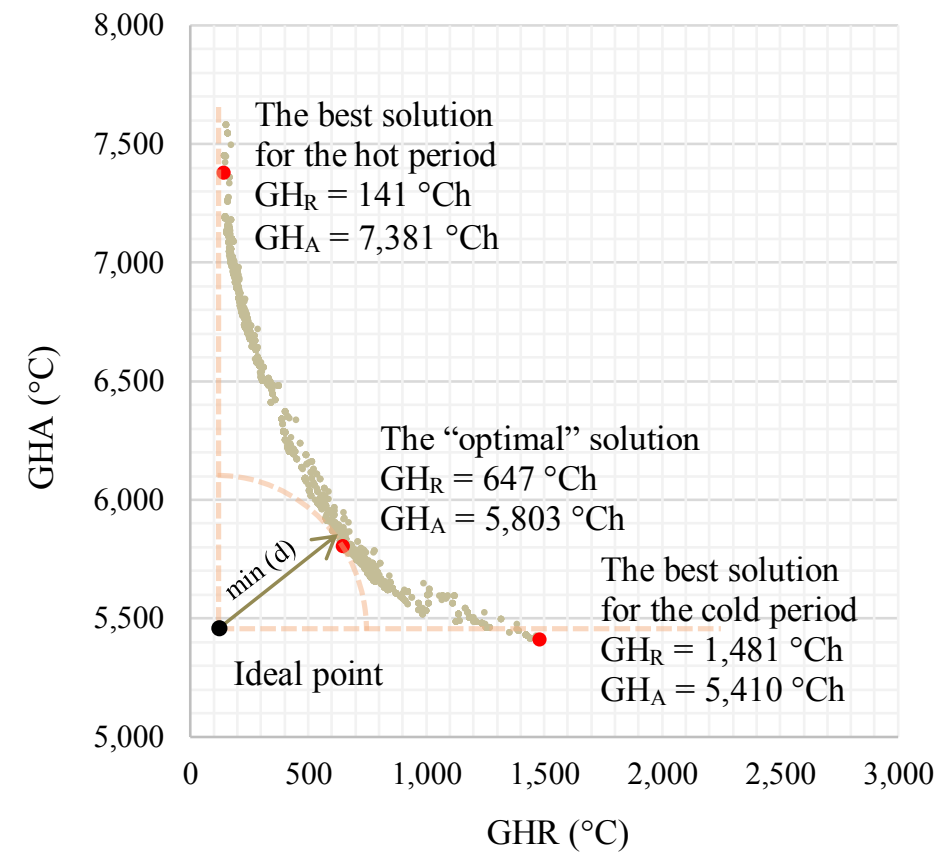

54 Berleze, A. S.; Brasileiro, A. de B. H.; Silvoso, M. M. 
Figure 12 - Set of Pareto-optimal solutions of the model "B"

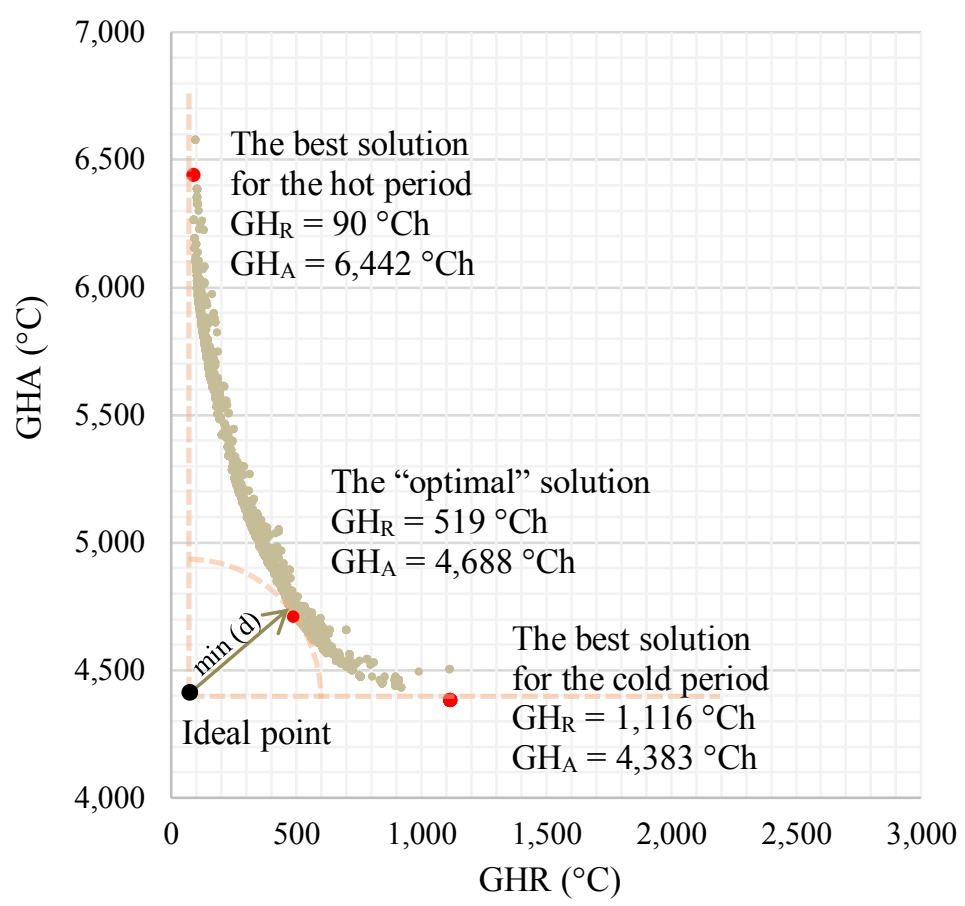

It is noticed that thermal discomfort due to cold $\left(\mathrm{GH}_{\mathrm{A}}\right)$ is much higher than discomfort due to heat $\left(\mathrm{GH}_{\mathrm{R}}\right)$, making it considerably easier to improve the thermal performance of the building during the hot period. The results indicate that it is practically possible to eliminate the heat discomfort in this region of the country based only on bioclimatic strategies and on the optimization of design parameters. Cold discomfort, however, was less sensitive to this approach, which confirms the need to use artificial heating systems complementing those of passive thermal conditioning.

From these results, three optimal solutions for each optimization were defined to make a more detailed analysis and understand which design parameter settings led to these best performances. The solutions chosen were:

(a) the solution with the best performance in the hot period (the lowest $\mathrm{GH}_{\mathrm{R}}$ );

(b) the solution with the best performance in the cold period (the lowest $\mathrm{GH}_{\mathrm{A}}$ ); and

(c) the solution with the best overall thermal performance (the shortest distance from the optimal Pareto solution to the ideal point).

In order to demonstrate the evolution of the study and the importance of the variables studied on the models, a comparison between the base model and the proposed "A" and "B" models was performed.

\section{The best thermal performance during the hot period (the lower $\mathrm{GH}_{\mathrm{R}}$ )}

The solutions that presented the best thermal performances in the hot period reached $\mathrm{GH}_{\mathrm{R}}$ values of up to 90 ${ }^{\circ} \mathrm{Ch}$ in Model "B" and $141^{\circ} \mathrm{Ch}$ in Model "A" (Figure 13). These results represent an improvement of $98 \%$ (Model "B") and 97\% (Model " $\mathrm{A}$ ") in relation to the $\mathrm{GH}_{\mathrm{R}}$ of the base model (Figure 14). Although this solution also showed an improvement in cold discomfort $\left(\mathrm{GH}_{\mathrm{A}}\right)$, it is much less significant $(14 \%$ in Model "A" and 25\% in Model "B"). This is due to the fact that we are dealing with contradictory objectives, where the design parameters that contribute to thermal performance in the hot period are usually the same as those that affect performance in the cold period and vice versa.

The definition of some parameters that lead to this solution may be intuitive, such as:

(a) use of light colors on the walls and roof (low external solar absorptance); and

(b) longer length of external shading. 
Figure 13 - Thermal performance between models with configuration of envelope that resulted in the best performance in the hot period

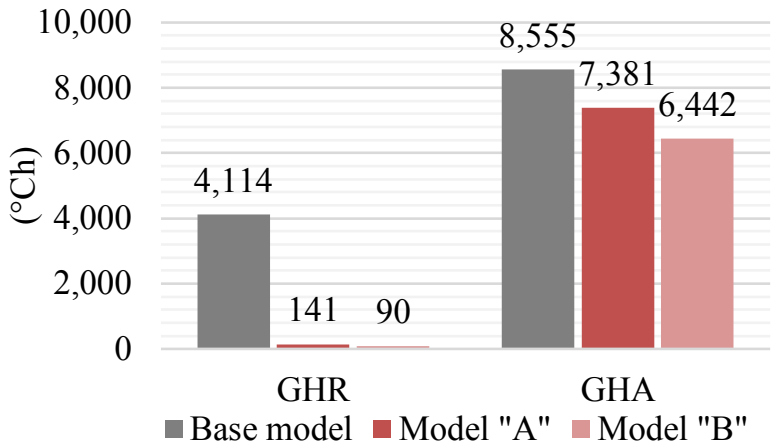

Figure 14 - Percentage improvement of the proposed models vs. base model - best performance in the hot period

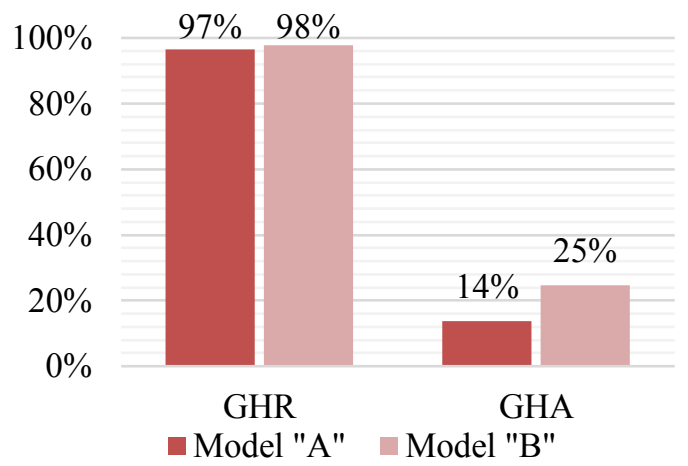

However, intuitively, we could think that larger ceiling height would contribute to better thermal performance, as well as larger windows for providing greater ventilation. These parameters were not confirmed in this study, since the opaque materials of the envelope that proved to be more adequate have greater thermal inertia. In this sense, they contribute to the higher thermal inertia of the building as a whole, (the lower ceiling and the smaller windows), regardless of the solar orientation.

In Model "A", the design parameters that contributed to this performance were:

(a) the largest width of the bedrooms (variable X);

(b) the greatest width and depth of social rooms (variables X2, Y2 and Y3); and

(c) the smallest WWR in all long-stay rooms.

In Model "B", the design parameters that contributed to this performance were: the smaller width of the bedrooms (variable X); the widest width of social rooms (variable X2) and the smallest WWR in all longstay rooms.

In addition, regarding the better orientation of the windows, the west orientation was not favorable in any case. The northern orientation was the most favorable, especially when combined with solar shading (Tables 7 and 8).

\section{The best thermal performance during the cold period (the lowest $\mathrm{GH}_{\mathrm{A}}$ )}

The solutions that resulted in the best thermal performance in the cold period reached $\mathrm{GH}_{\mathrm{A}}$ values of 5,410 ${ }^{\circ} \mathrm{Ch}$ for Model "A" and 4,383 ${ }^{\circ} \mathrm{Ch}$ for Model "B" (Figure 15), which represents an improvement of 49\% (Model "B") and 37\% (Model "A") (Figure 16) in relation to the thermal performance of the existing dwelling in the same period. It is noted that these solutions also contributed effectively in relation to the $\mathrm{GH}_{\mathrm{R}}(73 \%$ in Model "B" and 64\% in Model "A"), although not as well as in the previous case.

56 Berleze, A. S.; Brasileiro, A. de B. H.; Silvoso, M. M. 
Table 7 - Appropriate window orientation for Model "A"

\begin{tabular}{l|c|c}
\hline & With external shading & Without external shading \\
\hline Window Bedroom 1 (N or E) & North & East \\
Window Bedroom 2 (E or S) & East & South \\
Window Living Room (N or W) & North & North \\
\hline
\end{tabular}

Table 8 - Appropriate window orientation for Model “B”

\begin{tabular}{l|c|c}
\hline & With external shading & Without external shading \\
\hline Window Bedroom 2 (N or E) & North & North \\
Window Living Room (N or W) & North & North \\
Window Dining Room (W or S) & South & South \\
\hline
\end{tabular}

Figure 15 - Thermal performance between models with configuration of envelope that resulted in the best performance in the cold period

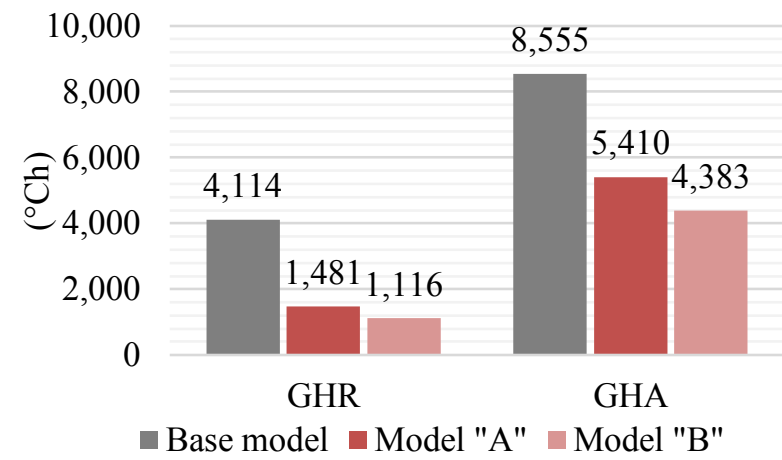

Figure 16 - Percentage improvement of the proposed models vs. base model - best performance in the cold period

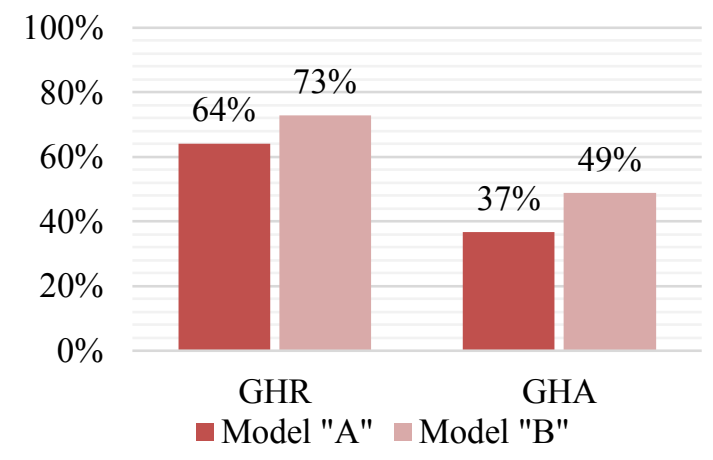

Likewise, it can be intuitive to think about which design parameter could contribute to a better thermal performance in the cold period, such as:

(a) use of dark colors on the walls and roof (medium/high solar absorptance); and

(b) shorter length of solar shading.

In this case, lower ceilings also contributed to better winter performance, as well as higher WWR (regardless of orientation) by providing greater passive solar gains.

In Model "A", the design parameters that contributed to this performance were:

(a) the greater width of the bedrooms and social rooms (variables $\mathrm{X}$ and $\mathrm{X} 2$ );

(b) an intermediate depth of social rooms (variables Y2 and Y3); and 
(c) the largest WWR in all long-stay rooms, except bedroom 2 with an east window orientation that should have an intermediate dimension.

In Model "B", the design parameters that contributed to this performance were: the greater width of the bedrooms and social rooms (variables X and X2); and dark color on the walls, but with $\alpha=0.7$, and not the greatest possible solar absorptance.

In relation to the best orientation of the windows, the orientation to the North was more appropriate again, probably because it provides greater passive solar gains throughout most of the day. For this situation, the orientation of the windows to the South should be avoided even more than to the West (Tables 9 and 10).

\section{The best overall thermal performance (the shortest distance to the ideal point)}

According to the proposed approach, calculated from Equation 2, the solution that presented the best global thermal performance reached a $\mathrm{GH}_{\mathrm{R}}$ of $647^{\circ} \mathrm{Ch}$ and a $\mathrm{GH}_{\mathrm{A}}$ of 5,803 ${ }^{\circ} \mathrm{Ch}$ in Model "A" (Figure 17), which represents an annual thermal discomfort of $6,450{ }^{\circ} \mathrm{Ch}$ (sum of the two partial discomforts). Model " $\mathrm{B}$ " reached a $\mathrm{GH}_{\mathrm{R}}$ of $519{ }^{\circ} \mathrm{Ch}$ and a $\mathrm{GH}_{\mathrm{A}}$ of $4,688{ }^{\circ} \mathrm{Ch}$, totaling an annual thermal discomfort of $5,207{ }^{\circ} \mathrm{Ch}$. These results represent an improvement for Model " $\mathrm{A}$ " of $84 \%$ in relation to $\mathrm{GH}_{\mathrm{R}}$ and $32 \%$ in relation to $\mathrm{GH}_{\mathrm{A}}$, when compared to the base model. As well as an improvement of $87 \%$ in relation to $\mathrm{GH}_{\mathrm{R}}$ and $45 \%$ in relation to $\mathrm{GH}_{\mathrm{A}}$ with the "B" model (Figure 18).

It is noted, therefore, that these solutions do not coincide with those analyzed in the two previous situations. On the contrary, they present an "intermediate" performance in relation to $\mathrm{GH}_{\mathrm{R}}$ and $\mathrm{GH}_{\mathrm{A}}$, but which, when added together, result in a global performance, throughout the year, better than the previous cases.

The design parameter settings that led to the best overall performance can be seen in Table 11 and shown in Figure 19.

It is noted, however, that in the case where we intend to prioritize the overall thermal performance of the building, we cannot intuit which design parameters to choose. In this case, only simulation-based optimization methods can indicate the ideal set of design parameters.

\section{Discussion}

In this article, the thermal performance was evaluated by an indicator of discomfort (degree-hours for cooling and heating), which is a method indicated for naturally ventilated buildings. The RTQ-R assesses only the thermal performance in the hot period using this method, which contributes to some reference values. According to the RTQ-R (INSTITUTO..., 2012), homes with a $\mathrm{GH}_{\mathrm{R}}$ below $143{ }^{\circ} \mathrm{Ch}$ (bioclimatic zone 1 - ZB 1), $822{ }^{\circ} \mathrm{Ch}$ (ZB3, bioclimatic zone of the study), $12.566{ }^{\circ} \mathrm{Ch}$ (ZB7), among others, could be classified as level "A" of efficiency. As shown in Figures 11 and 12, most of the solutions found in the optimization presented a $\mathrm{GH}_{\mathrm{R}}$ below $822{ }^{\circ} \mathrm{Ch}$, which indicates that the dwelling would have a thermal performance considered adequate, or even, excellent. This is the case, for example, with the solutions detailed in earlier.

Table 9 - Appropriate window orientation for Model "A"

\begin{tabular}{l|c|c}
\hline & With external shading & Without external shading \\
\hline Window Bedroom 1 $(\mathrm{N}$ or $\mathrm{E})$ & North & North \\
Window Bedroom 2 $(\mathrm{E}$ or $\mathrm{S})$ & East & East \\
Window Living Room $(\mathrm{N}$ or $\mathrm{W})$ & North & North \\
\hline
\end{tabular}

Table 10 - Appropriate window orientation for Model "B"

\begin{tabular}{l|c|c}
\hline & With external shading & Without external shading \\
\hline Window Bedroom 2 (N or E) & North & North \\
Window Living Room (N or W) & North & North \\
Window Dining Room (W or S) & West & West \\
\hline
\end{tabular}

58 Berleze, A. S.; Brasileiro, A. de B. H.; Silvoso, M. M. 
Figure 17 - Thermal performance between models with configuration of envelope that resulted in the best annual performance

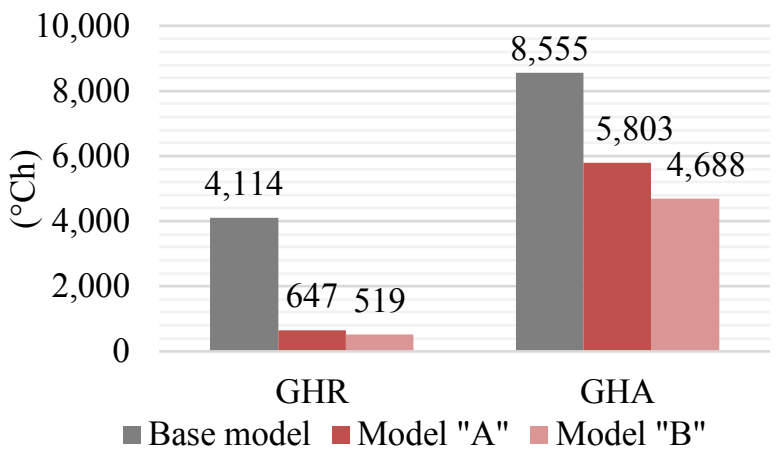

Figure 18 - Percentage improvement of the proposed models vs. base model - best annual performance

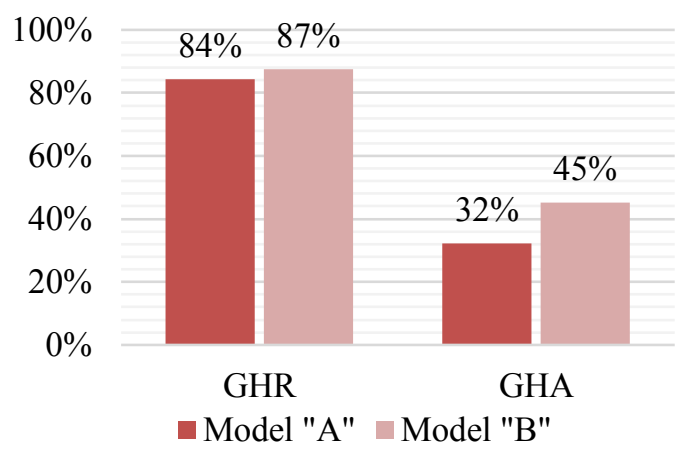

Table 11 - Parameter settings for Model "A" and Model "B" with the best annual thermal performance

\begin{tabular}{|c|c|c|}
\hline & Model "A" & Model "B" \\
\hline Solar absorptance of external walls & High & Medium/ high \\
\hline Dimension of external wall of LSR ${ }^{*}$ & Largest facing North & Largest facing North \\
\hline Floor dimension of LSR & Largest Possible & Largest Possible \\
\hline Window orientation of bedroom 1 (N or E) & North & North (B2) \\
\hline Window orientation of bedroom 2 (E or S) & East & - \\
\hline Window orientation of living room ( $\mathrm{N}$ or $\mathrm{W})$ & North & North \\
\hline Window orientation of dining room (W or S) & West (fixed) & South \\
\hline Dimension of windows to the North & $\begin{array}{l}\text { Large (with shading) } \\
\text { Small (without shading) }\end{array}$ & $\begin{array}{l}\text { Large (with shading) } \\
\text { Small/medium } \\
\text { (without shading) }\end{array}$ \\
\hline Dimension of windows to the East & $\begin{array}{l}\text { Small (with or without } \\
\text { shading) }\end{array}$ & $\begin{array}{l}\text { Small (with or without } \\
\text { shading) }\end{array}$ \\
\hline Dimension of windows to the West & $\begin{array}{l}\text { Small (with or without } \\
\text { shading) }\end{array}$ & $\begin{array}{l}\text { Small (with or without } \\
\text { shading) }\end{array}$ \\
\hline Dimension of windows to the South & - & Small \\
\hline Dimension of external shadings to the North & Medium $(40 \mathrm{~cm})$ & Medium $(40 \mathrm{~cm})$ \\
\hline Dimension of external shadings to the East & Medium $(40 \mathrm{~cm})$ & Medium $(40 \mathrm{~cm})$ \\
\hline Dimension of external shadings to the West & Large $(100 \mathrm{~cm})$ & Large $(100 \mathrm{~cm})$ \\
\hline
\end{tabular}

Note: "Long-stay room, (e.g. bedrooms and living rooms). 
Figure 19 - Visualization of the models that presented better thermal performances throughout the year $\left(\mathrm{GH}_{\mathrm{ANUAL}}\right)$
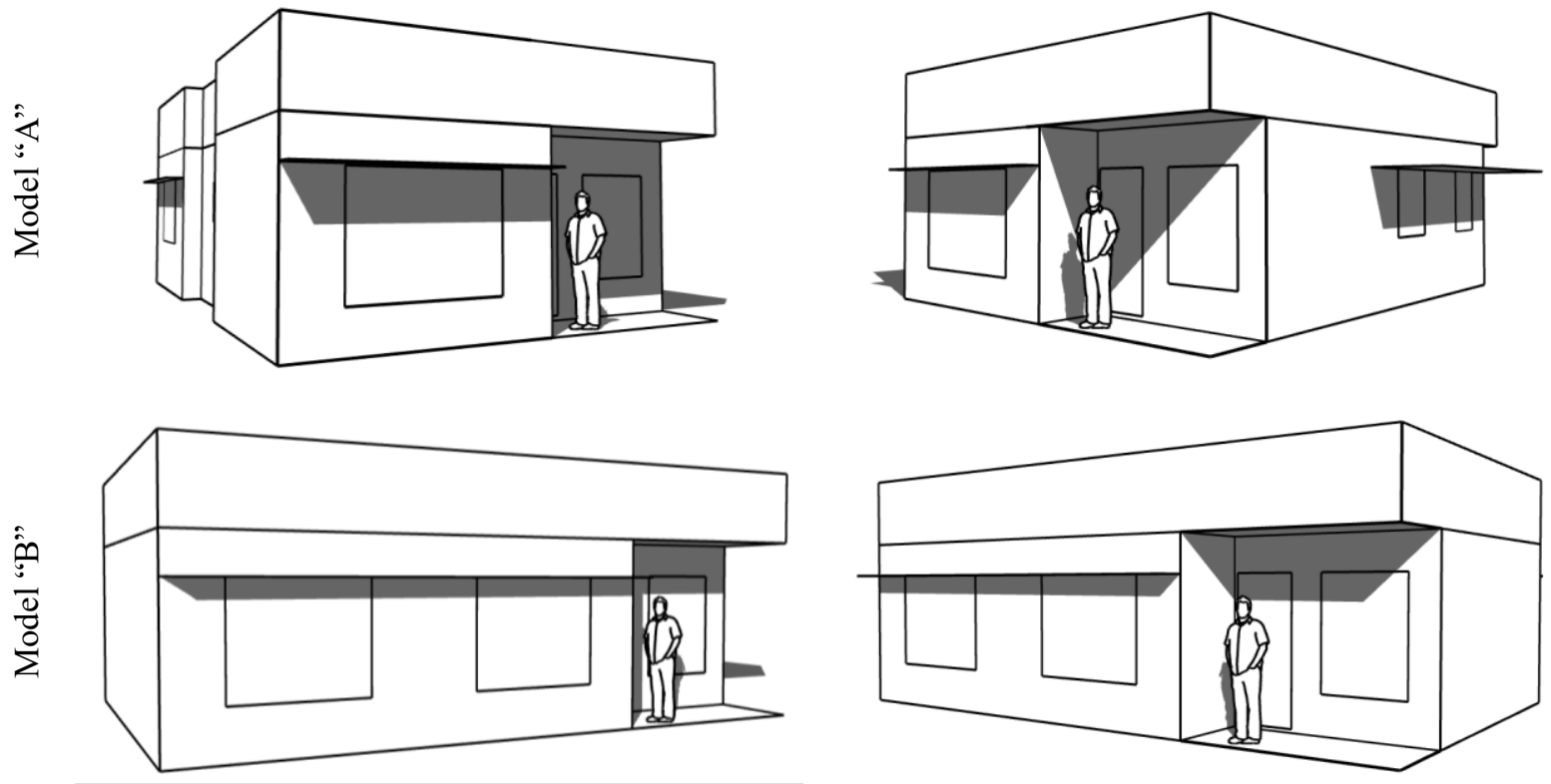

There are no reference values for $\mathrm{GH}_{\mathrm{A}}$. However, if $\mathrm{GH}_{\mathrm{R}}$ values less than $12.566{ }^{\circ} \mathrm{Ch}$ are considered adequate for ZB7, values of this order of magnitude could be accepted in the case of cold discomfort in regions where this climate is more severe. The highest $\mathrm{GH}_{\mathrm{A}}$ value found in this study was $7,582{ }^{\circ} \mathrm{Ch}$ and among the detailed solutions, the highest $\mathrm{GH}_{\mathrm{A}}$ analyzed was $7,381{ }^{\circ} \mathrm{Ch}$ (referring to the solution that presented the best performance in the hot period - model " $\mathrm{A}$ "). Therefore, it is concluded that although the $\mathrm{GH}_{\mathrm{A}}$ values have a higher order of magnitude in relation to $\mathrm{GH}_{\mathrm{R}}$, they could still be adequate and compatible with good levels of energy efficiency.

On the other hand, it is important to clarify that this indicator is formed by two different data, degrees and hours. This means that a certain degree-hour value could represent many hours in discomfort, with little variation in the internal operating temperature in relation to the comfort temperature; or it could represent less hours in discomfort, but with a greater variation of the internal temperature in relation to the comfort temperature. This analysis, however, is not obtained directly through the method used here.

Bre and Fachinotti (2017) found optimal solutions for single-family houses in Argentina that achieved up to $95 \%$ improvement in the thermal comfort of naturally ventilated rooms using design parameters similar to those used in this study. In their case, discomfort in the hot period was the biggest problem. The base model presented $2,236{ }^{\circ} \mathrm{Ch}$ for $\mathrm{GH}_{\mathrm{R}}$ and $1,454^{\circ} \mathrm{Ch}$ for $\mathrm{GH}_{\mathrm{A}}$, while the two optimized models presented $45^{\circ} \mathrm{Ch}$ and $8{ }^{\circ} \mathrm{Ch}$ of $\mathrm{GH}_{\mathrm{R}}$; and $120^{\circ} \mathrm{Ch}$ and $80{ }^{\circ} \mathrm{Ch}$ of $\mathrm{GH}_{\mathrm{A}}$.

Bre et al. (2016) found solutions with 91\% less than total degrees-hour in naturally ventilated environments. In this study, the same base model was used in Argentina. But in this case, the two optimized models presented $139{ }^{\circ} \mathrm{Ch}$ and $70{ }^{\circ} \mathrm{Ch}$ of $\mathrm{GH}_{\mathrm{R}}$; and $179{ }^{\circ} \mathrm{Ch}$ and $150{ }^{\circ} \mathrm{Ch}$ of $\mathrm{GH}_{\mathrm{A}}$. These results were also achieved by combining bioclimatic strategies such as thermal inertia and natural ventilation.

These results serve to demonstrate the order of magnitude of the performance indicator, similar to the $\mathrm{GH}_{R}$ found in this study, as well as to demonstrate the potential for improvement through the use of multiobjective optimization methods.

In relation to the envelope, it is important to note that the wall and roof materials have high thermal inertia, which has already been confirmed as an important factor for the thermal performance of naturally ventilated buildings (BRITO; AKUTZU; TRIBESS, 2011). Bre and Fachinotti (2017) also achieved the best thermal performance with external walls with high thermal capacity and high thermal delay. According to NBR 15220 (ABNT, 2005), social housing located in ZB 3 must have external wall with: $\mathrm{U}$-value $\leq 3.6 \mathrm{~W} / \mathrm{m}^{2} . \mathrm{K}$, $\varphi \leq 4.3$ hours and $\mathrm{SF} \leq 4.0$; and roofs with: U-value $\leq 2.0 \mathrm{~W} / \mathrm{m}^{2} . \mathrm{K}, \varphi \leq 3.3$ hours and $\mathrm{SF} \leq 6.5$ ). In a previous study, Berleze (2020) found that some of the roofs that would fit the recommendation of NBR 
15220 and NBR 15575 had the worst thermal performance among others studied. Of these, the roof that presented the best results was the one used in this study and which is not recommended by NBR 15220 nor valued by NBR 15575 . The same occurs in relation to the type of external wall used in this study, which is not recommended by NBR 15220, however, it presented the best thermal performance in the previous study.

The thermal performance was significantly optimized in relation to the existing building. However, in the cold period, neither the use of materials with high thermal inertia nor the variation of the design parameters were able to provide passive thermal comfort. The use of artificial heating systems is still necessary during this period of the year. This demonstrates that only passive strategies would not be enough to provide thermal comfort in the winter period, unlike researches in other cities of the same bioclimatic zone (FONSECA et al., 2017; LAMBERTS et al., 2010). The winter in Chapecó is more rigorous than in the locations of these other studies, confirming the results of the bioclimatic analysis and emphasizing the climatic differences within the same BZ.

Although the orientation of the building has not been directly assessed in this study, models "A" and "B" represent buildings with a greater facade facing East/West and North/South, respectively. In this study, the "B" model, with the largest North/South façade, proved to be more adequate in relation to thermal performance, as already expected.

\section{Recommendations for new social housing in Chapecó/SC (Brazil)}

Considering the work results achieved, it was possible to make recommendations for future low-income housing located in Chapecó/SC (Figure 20), with a floor area of approximately $48 \mathrm{~m}$ and solar orientation of the main façade to the North, the following configurations are recommended in relation to the opaque envelope and the geometry of the building.

\section{Conclusions}

In this article, a simulation-based optimization method for improving the thermal performance of naturally ventilated social housing was proposed. The thermal performance was optimized by minimizing two objective-functions, referring to the degree-hours of cooling $\left(\mathrm{GH}_{\mathrm{R}}\right)$ and heating $\left(\mathrm{GH}_{\mathrm{A}}\right)$. Two hypothetical " $A$ " and "B" models were modeled parametrically and integrated to an optimization engine and to a building performance simulation software (EnergyPlus). 15 and 14 design parameters were defined, respectively, as well as their variation intervals, such as: the dimensions of the long-stay rooms, the orientation and dimension of the windows of the LSR and the position and dimensioning of horizontal solar shadings in the windows of the LSR. Some presets about the materials and the geometry of the model were based on studies previously developed by Berleze (2020), such as: use of heavy opaque envelope, the $2.5 \mathrm{~m}$ ceiling height and the low absorptance of the roof.

These models were compared to a base model, which corresponds to the existing dwelling found in the Loteamento Expoente, in Chapecó. In this model, building performance simulation techniques were applied, based on the configuration of real parameters, specified in the project.

The method used in this study resulted in a high number of Pareto solutions. In all cases, there was an improvement in thermal performance for both climatic conditions (hot and cold period) compared to the base model. One of the challenges of this method is to identify which solution to prioritize among so many almost optimal solutions, that is, to understand the best trade-off between summer and winter performance (contradictory objectives). This same difficulty has already been pointed out by Ascione et al. (2016). It is understood that any of these solutions would be considered a good choice, but it would only prioritize one or another period of the year. Here, we overcome this difficulty based on an approach based on the shortest distance from Pareto's optimal solutions to the ideal point.

The results of the simulation-based optimization of models " $\mathrm{A}$ " and "B" showed significant improvements in thermal performance when compared to the base model, reaching improvements of up to $98 \%$ in the hot period and $49 \%$ in the cold period.

When we want to prioritize thermal comfort at any time of the year (hot or cold), some sets of design parameter can be chosen intuitively for an experienced architect. But the architect's empirical knowledge is not always enough to generate architectural projects appropriate to the climate. When the objective is to prioritize thermal performance throughout the year, in regions where summers and winters are well defined, only simulation and optimization methods can indicate with precision which design parameter will be most appropriate. 
Figure 20 - Recommendation list

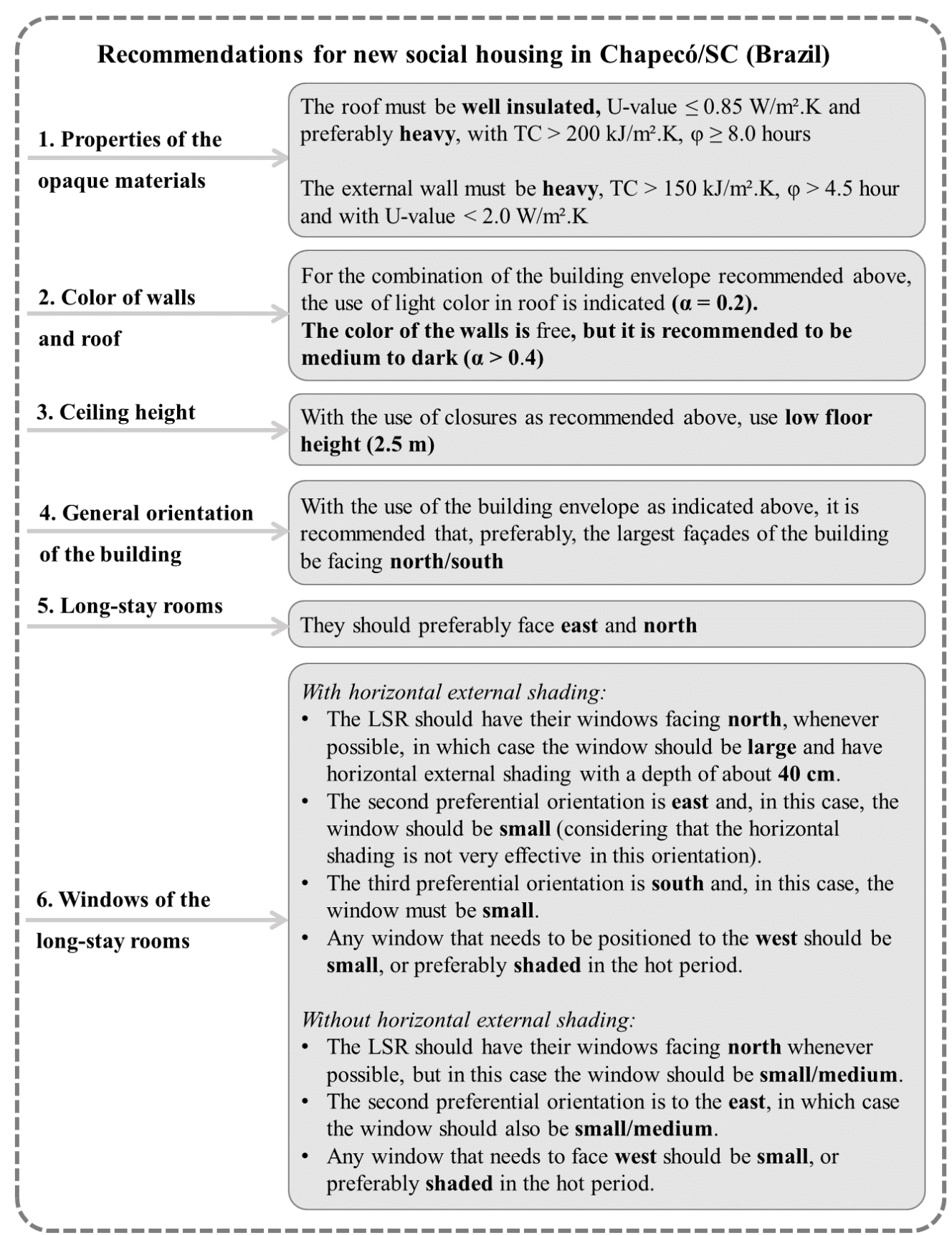

The results confirm that the use of parametric tools combined with optimization techniques has a high potential for use, and can assist architects in the search for the most appropriate design configurations aiming at the creation of efficient buildings and/or that provide greater thermal comfort to residents.

Finally, the solutions that best met the objective functions were used to support the creation of design recommendations on geometry and construction elements with regard to thermal performance. It is hoped that the recommendations listed here will assist architects in decision making during the initial phases of the architectural design of new social housing in Chapecó/SC and may also be useful as methodological guidelines for projects in other locations. 


\section{References}

ANALYSISBIO. Software livre. Disponível em: http://www.labeee.ufsc.br/downloads/ softwares. Acesso em: 9 set. 2018 .

ASCIONE, F. et al. Optimization of building envelope design for nZEBs in Mediterranean climate: performance analysis of residential case study. Applied Energy, v. 183, p. 938-957, 2016.

ASSOCIAÇÃO BRASILEIRA DE NORMAS TÉCNICAS. NBR 15220-3: desempenho térmico de edificações: parte 3: zoneamento bioclimático brasileiro e diretrizes construtivas para habitações unifamiliares de interesse social. Rio de Janeiro, 2005.

BADER, J.; ZITZLER, E. HypE: an algorithm for fast hypervolume-based many-objective optimization. Computer Engineering and Networks Laboratory. Zurich: ETH, 2008.

BERLEZE, A. S. Desempenho funcional e térmico, parametrização e otimização multiobjetivo: aplicações para habitações sociais unifamiliares em Chapecó/SC. Rio de Janeiro, 2020. Tese (Doutorado em Arquitetura e Urbanismo) - Programa de Pós-Graduação em Arquitetura e Urbanismo, Universidade Federal do Rio de Janeiro, Rio de Janeiro, 2020.

BICHIOU, Y.; KRARTI, M. Optimization of envelope and HVAC systems selection for residential buildings. Energy and Buildings, v. 43, p. 3373-3382, 2011.

BORTOLI, K. C. R. de; VILLA, S. B. Adequação ambiental como atributo facilitador da resiliência no ambiente construído em Habitações de Interesse Social. Ambiente Construído, Porto Alegre, v. 20, n. 1, p. 391-422, jan./mar. 2020

BRASIL. Ministério da transparência, fiscalização e controle. Secretaria federal de controle interno.

Relatório de Avaliação da Execução de Programa de Governo n 66 - Programa Minha Casa, Minha Vida - FGTS. Brasília, 2017. Disponível em: https://auditoria.cgu.gov.br/download/9775.pdf. Acesso em: 19 abr. 2018.

BRE, F. et al. Residential building design optimisation using sensitivity analysis and genetic algorithm. Energy and Buildings, v. 133, p. 853-866, 2016.

BRE, F.; FACHINOTTI, V. D. A computational multi-objective optimization method to improve energy efficiency and thermal comfort in dwellings. Energy and Buildings, v. 154, p. 283-294, 2017.

BRE, F.; ROMAN, N.; FACHINOTTI, V. D. An efficient metamodel-based method to carry out multiobjective building performance optimizations. Energy and Buildings, v. 206, p. 109576, 2020.

BRITO, A. C.; AKUTSU, M.; TRIBESS, A. Emprego do programa computacional EnergyPlus na análise de alternativas de projeto de habitação visando o conforto térmico do usuário. In: IBERIAN LATIN AMERICAN CONGRESS ON COMPUTATIONAL METHODS IN ENGINEERING, Ouro Preto, 2011. Proceedings [...] Ouro Preto, 2011.

CAIXA ECONÔMICA FEDERAL. Habitação. Minha Casa Minha Vida. Habitação Urbana. Empreendimentos Minha Casa Minha Vida. 2018. Disponível em: http:/www.caixa.gov.br/voce/habitacao/ minha-casa-minha-vida/urbana/Paginas/default.aspx. Acesso em: 27 fev. 2018.

ELETROBRAS. PROCEL. Pesquisa de posse e hábitos de uso de equipamentos elétricos na classe residencial. Rio de Janeiro, 2019. Disponível em: https://eletrobras.com/pt/Paginas/ PPH-2019.aspx. Acesso em: 15 jul. 2020.

EMPRESA DE PESQUISA ENERGÉTICA. Balanço energético nacional 2019: ano base 2018. Rio de Janeiro: EPE, 2019.

ENERGYPLUS. Programa EnergyPlus. Disponível em: https://energyplus.net. Acesso em: 18 set. 2020.

FONSECA, L. P. G. et al. Otimização multiobjetivo das dimensões dos ambientes de uma residência unifamiliar baseada em simulação energética e estrutural. Ambiente Construído, Porto Alegre, v. 17, n. 1, p. 267-288, jan./mar. 2017.

FUNDAÇÃO JOÃO PINHEIRO. Déficit habitacional no Brasil. Disponível em:

http://novosite.fjp.mg.gov.br/deficit-habitacional-no-brasil/. Acesso em: 20 jan. 2020. 
G1. Minha Casa Minha Vida completa 10 anos com queda nas contratações. Disponível em: https:/g1.globo.com/economia/noticia/2019/03/25/minha-casa-minha-vida-completa-10-anos-com-quedanas-contratacoes.ghtml. Acesso em: 10 jan. 2020.

GIVISIEZ, G. H. N.; OLIVEIRA, E. L. (org.). Demanda futura por moradias: demografia, habitação e mercado. Niterói: Universidade Federal Fluminense, 2018.

HAMDY, M.; HASAN, A.; SIREN, K. Applying a multi-objective optimization approach for design of lowemission cost-effective dwellings. Building and Environment. v. 46, p. 109-123, 2011.

INSTITUTO BRASILEIRO DE GEOGRAFIA E ESTATÍSTICA. Habitação. Disponível em: https://www.ibge.gov.br/ estatisticas-novoportal/sociais/habitacao/17270-pnad-continua. Acesso em: 20 jun. 2020 .

INSTITUTO NACIONAL DE METEOROLOGIA. Clima. Disponível em: https:/clima.inmet.gov.br/GraficosClimatologicos/DF/83377. Acesso em: 10 set. 2020.

INSTITUTO NACIONAL DE METROLOGIA, QUALIDADE E TECNOLOGIA. Regulamento Técnico da Qualidade Para o Nível de Eficiência Energética de Edificações Residenciais - RTQ-R. Rio de Janeiro, 2012.

JIN, J. T.; JEONG, J. W. Optimization of a free-form building shape to minimize external thermal load using genetic algorithm. Energy and Buildings, v. 85, p. 473-482, 2014.

KITCHLEY, J. J. L.; SRIVATHSAN, A. Generative methods and the design process: A design tool for conceptual settlement planning. Applied Soft Computing, v.14, p. 634-652, 2014.

LAMBERTS, R. et al. Casa eficiente: bioclimatologia e desempenho térmico. Florianópolis: UFSC/LabEEE, 2010.

MAGNIER, L. Multiobjective optimization of building design using artificial neural network and multiobjective evolutionary algorithms. Quebec, 2008. Ph.D Thesis in Applied Science (Building Engineering) at Concordia University Montreal, Quebec, 2008.

MARTINO, J. A. Algoritmos evolutivos como método para desenvolvimento de projetos de arquitetura. Campinas, 2015. Tese (Doutorado em Arquitetura, Tecnologia e Cidade) - Faculdade de Engenharia Civil, Arquitetura e Urbanismo, Universidade Estadual de Campinas, Campinas, 2015.

NGUYEN, A.; REITER, S.; RIGO, P. A review on simulation-based optimization methods applied to building performance analysis. Applied Energy, v. 113, ago. 2014.

PROCEL. Resultados PROCEL 2014: ano base 2013. 2014. Disponível em:

http://www.procelinfo.com.br/main.asp?. Acesso em: $12 \mathrm{dez} .2015$.

RHINO3D. Rhinoceros. Grasshopper. Disponível em: https:/www.rhino3d.com/download. Acesso em: 18 set. 2020.

SANTANA, L. O. Otimização multiobjetivo da geometria de edificações residenciais energeticamente eficientes por meio de algoritmos genéticos. Viçosa, 2016. Dissertação (Mestrado em Arquitetura e Urbanismo) - Programa de Pós-Graduação em Arquitetura e Urbanismo, Universidade Federal de Viçosa, Viçosa, 2016.

SANTOS, T. L. dos; PORTO , F. H. F. dos S.; SILVA, A. S. Análise da correlação entre conforto e desempenho térmico em habitações de interesse social por simulação computacional. Ambiente Construído, Porto Alegre, v. 20, n. 2, p. 211-229, abr./jun. 2020.

SOLEMMA. Diva. Archsim. Available: https:/www.solemma.com/Download.html. Access: 18 set. 2020.

SORGATO, M. J. Desempenho térmico de edificações residenciais unifamiliares ventiladas naturalmente. Florianópolis, 2009. Dissertação (Mestrado em Engenharia Civil) - Programa de PósGraduação em Engenharia Civil, Universidade Federal de Santa Catarina, Florianópolis, 2009.

SUGA, K.; KATO, S.; HIYAMA, K. Structural analysis of Pareto-optimal solution sets for multi-objective optimization: An application to outer window design problems using Multiple Objective Genetic Algorithms. Building and Environment, v. 45, p. 1144-1152, 2010.

SWAMI, M. V.; S. CHANDRA. Correlations for pressure distribution on buildings and calculation of natural-ventilation airflow. ASHRAE Transactions, v. 94, part 1, p. 243-266, 1988. 
TRIANA, M. A.; LAMBERTS, R.; SASSI, P. Characterization of representative building typologies for social housing projects in Brazil and its energy performance. Energy Policy, v. 87, p. 524-541, 2015.

TUBELO, R. et al. Cost-effective envelope optimisation for social housing in Brazil's moderate climates zones. Building and Environment, v. 133, p. 213-227, 2018.

UNITED NATIONS ENVIRONMENT PROGRAM. Sustainable building. Disponível em: https://www.unenvironment.org/explore-topics/resource-efficiency/what-we-do/cities/sustainable-buildings. Acesso em: 20 ago. 2020.

YU, W. et al. Application of multi-objective genetic algorithm to optimize energy efficiency and thermal comfort in building design. Energy and Buildings, v. 88, p. 135-143. 2015.

ZHANG, J.; LIU, N.; WANG, S. A parametric approach for performance optimization of residential building design in Beijing. Building Simulation, v. 13, n. 2, p. 223-235, 2020.

ZITZLER, E.; LAUMANNS, M.; THIELE, L. SPEA-2: improving the strength Pareto evolutionary algorithm. Computer Engineering and Networks Laboratory. Zurich: ETH, 2001.

\section{Angélica Saccol Berleze}

Departamento de Arquitetura e Urbanismo | Universidade Federal de Viçosa | Av. Peter Henry Rolfs, s/n, Campus Universitário | Viçosa MG - Brasil | CEP 36570-900 | Tel.: (31) 3612-6001 | E-mail: angelicaberleze@gmail.com

\section{Alice de Barros Horizonte Brasileiro}

Departamento de Tecnologia da Construcão | Universidade Federal do Rio de Janeiro | Av. Pedro Calmon, 550, Prédio da Reitoria, $4^{\circ}$ andar, Sala 422, Cidade Universitária | Rio de Janeiro - RJ - Brasil | CEP 21941-901 | Tel.: (21) 3938-0285 | E-mail:

alicebrasileiro@fau.ufrj.br

\section{Marcos Martinez Silvoso}

Programa de Pós-Graduação em Arquitetura | Universidade Federal do Rio de Janeiro | Av. Pedro Calmon, 550, Prédio da Reitoria, $4^{\circ}$ andar, Sala 433, Cidade Universitária | Rio de Janeiro - RJ - Brasil | CEP 21941-590 | Tel.: (21) 3938-0288 | E-mail: silvoso@fau.ufrj.br

\section{Ambiente Construído}

Revista da Associação Nacional de Tecnologia do Ambiente Construído

Av. Osvaldo Aranha, $99-3^{\circ}$ andar, Centro

Porto Alegre - RS - Brasil CEP $90035-190$

Telefone: +55 (51) 3308-4084

Fax: +55 (51) 3308-4054

www.seer.ufrgs.br/ambienteconstruido

E-mail: ambienteconstruido@ufrgs.br 